\title{
Who Will Defend Democracy? Evaluating Tradeoffs in Candidate Support Among Partisan Donors and Voters*
}

\author{
John Carey \\ Department of Government \\ Dartmouth College
}

Gretchen Helmke

Department of Political Science

University of Rochester

\author{
Mitchell Sanders \\ Director of Survey Research \\ Bright Line Watch
}

\author{
Katherine Clayton \\ Department of Political Science \\ Stanford University \\ Brendan Nyhan \\ Department of Government \\ Dartmouth College
}

\author{
Susan Stokes \\ Department of Political Science \\ University of Chicago
}

\begin{abstract}
Scholars and pundits fear that the American public's commitment to democracy is declining and that citizens are willing to embrace candidates who would trample democratic principles. We examine whether violations of those principles generate resistance from both voters and top campaign donors and whether such resistance extends across partisan lines. In a conjoint survey experiment, we investigate how regular citizens and donor elites trade off partisanship, policy positions, and support for democratic values when choosing between hypothetical political candidates. Our findings indicate that both citizens and donors punish candidates who endorse violations of democratic principles irrespective of party. However, we find partisan polarization (especially among donors) in the effects of candidates supporting voter identification laws that threaten access to the franchise. These results suggest that the public and donors may sometimes be willing to forgive transgressions against democratic norms that align with their partisan and policy preferences.
\end{abstract}

${ }^{*}$ We thank Kevin Kromash for excellent administrative support and Yusaku Horiuchi for useful comments, and we gratefully acknowledge funding from Democracy Fund, the Hewlett Foundation, and Wilhelm Merck. 


\section{Introduction}

In recent years, prominent studies have argued that public commitment to democratic values in the U.S. has declined (Foa and Mounk 2016; Wike and Fetterolf 2018). Though these findings are contested (e.g., Voeten 2016), Americans are becoming more partisan (e.g., Pew Research Center 2017) and more likely to have strong feelings of in-group loyalty and out-group rivalry (Mason 2018). In that context, voters' willingness to tolerate violations of democratic principles by copartisans may also increase (Fishkin and Pozen 2018). In this way, increasing partisan antagonism could threaten the stability of the U.S. political system, which relies on consensual support of democratic norms (Levitsky and Ziblatt 2018).

A new line of research seeks to evaluate this risk by examining how voters make trade-offs between partisanship, public policy, and democratic values (Svolik 2018). Most notably, Graham and Svolik (2019) find that partisan and policy considerations have much stronger effects on vote choice among hypothetical political candidates than "undemocratic" platforms related to electoral fairness or checks and balances. Other research considers the influence of elite preferences on policy outcomes via campaign donations (Gilens 2012; Bonica et al. 2013; Gilens and Page 2014). Notably, studies show that donors are more polarized and partisan than the general public (Barber 2016; Broockman and Malhotra 2018; Gerber, Gooch, and Huber 2017), but are also more educated than the general public. As a result, expectations about donors' commitment to democratic values are unclear, which has potentially troubling implications for U.S. democracy given the role that elites are thought to play in preserving democratic stability (Weingast 1997).

We merge these lines of research to contrast the democratic commitments of the American public and elite campaign donors. Rather than simply asking abstract questions about support for democratic norms, we use a conjoint survey experiment to assess the effects of positions related to democratic principles on the likelihood of choosing a hypothetical candidate (as well as the effects of partisanship and policy stances). To understand whether voters will punish candidates who violate democratic principles, we estimate the effects of candidates broadly supporting or rejecting four salient democratic values: deference to court decisions, impartial investigations, 
legislative compromise, and equal access to the ballot. Our results indicate that partisanship exerts a powerful influence on candidate choice, although the effect of candidate party is less for donors than for the general public. Policy positions exert a substantial influence on candidate choice too, particularly for GOP donors on tax policy. Most importantly, both citizens and donors on either side of the partisan divide punish candidates who violate democratic norms on judicial deference, impartial investigations, and compromise. However, we find substantial polarization by party on voter identification laws, a policy issue that threatens the democratic principle of equal access to the franchise. On this issue, donors are even more polarized than the public.

\section{Research design}

We administered identical online conjoint experiments in March/April 2019 to a nationally representative sample of U.S. citizens provided by YouGov $(n=954)$ and a sample of individuals in the top $1 \%$ of donors by total contribution amount to federal campaigns $(n=570) .1,2,3$ Prior research shows that the conjoint design approximates real-world behavior (Hainmueller, Hangartner, and Yamamoto 2015), and that it effectively mitigates the social desirability bias that limits our ability to draw inferences about public opinion with traditional survey questions (Horiuchi, Markovich, and Yamamoto 2020). Our design also allows us to directly contrast the views of the public as a whole with those of the elite donors who are often presumed to be the most influential in national and party politics.

In the surveys, respondents were presented with ten pairwise choices between hypothetical candidates. The characteristics of the candidates were randomly selected. Candidates names were selected from a list of 123 names designed to signal both gender (man or woman) and race/ethnicity

\footnotetext{
${ }^{1}$ The experiments received approval from the OMITTED FOR PEER REVIEW.

${ }^{2}$ More details on how we recruited this sample, as well as summary statistics (see Tables A1 and A2) and information on response rates, are included in the Online Appendix.

${ }^{3}$ In October 2018, we conducted an identical conjoint candidate choice experiment on a representative sample of the American public only. We preregistered hypotheses about trade-offs among partisanship, policy, and democratic values in this sample at EGAP (ID: OMITTED FOR PEER REVIEW). We did not preregister separate hypotheses for our March/April 2019 samples. Results for tests of our preregistered hypotheses are provided in the Online Appendix.
} 
(white, black, or Hispanic) (see Butler and Homola 2017). ${ }^{4}$ The candidate's partisanship could be Democrat or Republican. Each candidate held two policy positions, which reflect salient party differences over policy on racial discrimination and taxation.

We varied candidate positions on four key democratic principles that were chosen based on findings from expert surveys and their relevance to contemporary debates and prior research (Carey et al. 2019; Levitsky and Ziblatt 2018; Svolik 2018):

- Judicial deference: Institutional checks on executive authority are widely regarded as an essential component of liberal democracy (V-Dem 2018). Respect for court decisions, even politically unfavorable ones, is essential to the effectiveness of such checks and to the rule of law more generally. Efforts by politicians to intimidate judges-for instance, by portraying them as corrupt or incompetent and questioning the legitimacy of their decisions-frequently signal the early stages of democratic erosion (Helmke and Rosenbluth 2009; Mounk 2018). ${ }^{5}$

- Impartial investigations: Legal investigations that are free from partisan influence are an essential element of the rule of law. When politicians or parties are able to appoint, intimidate, or control legal investigations, those who hold elected office can escape effective oversight and even potentially target their political opponents with harassment and politically motivated legal sanctions (Fishkin and Pozen 2018). Given the timing of the survey and the partisan debates over the Mueller report, this principle was particularly salient.

- Compromise: The peaceful resolution of political conflict requires acceptance of policy outcomes that are less than outright victories (Habermas 1994; Gutmann and Thompson 2012). Scholars from Berelson (1952) to Levitsky and Ziblatt (2018) contend that mutual toleration among political adversaries and forbearance in exercising power-which, together, describe compromise-are essential elements of democratic citizenship that sustain all other democratic principles, including the rule of law, electoral integrity, and individual rights.

\footnotetext{
${ }^{4}$ Candidate gender was randomized with probability 0.5 . Candidate race/ethnicity was randomized to be white, black, or Hispanic with probabilities $0.6,0.2$, and 0.2 , respectively, to approximate race/ethnicity in the general population and among candidates for public office.

${ }^{5}$ Graham and Svolik (2019) include a very similar statement to ours in their recent conjoint experiment: "Said the [own party] governor should ignore unfavorable court rulings by [opposite party]-appointed judges."
} 
- Ballot access: Advocates of voter ID laws argue that they are necessary to combat voter fraud, but research shows that voter fraud is exceedingly rare (Levitt 2007; Minnite 2010; Cottrell, Herron, and Westwood 2018), and that racial and ethnic minorities are far more likely than whites to lack the documentation such laws would require (Ansolabehere and Hersh 2017; Barreto et al. 2019). The net effects of voter ID laws on voter participation remain the subject of intense scholarly debate and sustained investigation (Rocha and Matsubayashi 2014; Hajnal, Lajevardi, and Nielson 2017; Hopkins et al. 2017; Valentino and Neuner 2017; Burden 2018; Grimmer et al. 2018; Neiheisel and Horner 2019) but in the absence of evidence for the problem they ostensibly address, their potentially disparate effects by race and ethnicity undermine the principle that all citizens should have an equal opportunity to vote and that participation in elections should be high (Sargent 2018).

For examples of violations of these norms in contemporary American politics, see Mikelionis (2019), New Voting Restrictions in America (2019), Siegel and Wiersema (2017), and Barr (2010). We acknowledge potential differences in the relative salience and political valence of these principles, which are not necessarily universally endorsed among citizens. These differences may explain the differing results we observe in our empirical results below, which we discuss further in the conclusion. ${ }^{6}$

In the conjoint tables, candidate names always appeared at the top followed by partisanship following the convention when information about candidates is provided to voters in standardized formats (e.g., on ballots and in voter guides). We randomized the order of other attributes besides name and party across participants, and did not implement any cross-attribute constraints. ${ }^{7}$

Based on respondents' pairwise choices, we calculate the Average Marginal Component Effect (AMCE) for each level on each attribute (Hainmueller, Hopkins, and Yamamoto 2014), and display the results in coefficient plots that show the average effect of changing each candidate attribute on

\footnotetext{
${ }^{6}$ In the conclusion, we also discuss the need for further research into the effects of other types of violations of democratic norms.

${ }^{7}$ The Online Appendix includes an illustrative example of a conjoint table used in our experiment (see Figure A1) and more details on the attributes included.
} 
the probability of candidate choice relative to a baseline attribute level. Per Abramson, Koçak, and Magazinnik (2019), this estimand does not indicate which attribute a majority of participants prefer in a binary sense, but instead represents an average effect of an attribute (relative to some baseline) on the probability of candidate choice conditional on other randomized attributes. Our language accordingly reflects the nature of this estimand, which is more akin to average treatment effects in survey experiments than expressions of a population's binary preference among attributes. ${ }^{8}$

\section{Results}

The results from our survey experiments are illustrated in Figure 1. We find no measurable effect of candidate race/ethnicity or gender on candidate choice behavior among either donors or the public. By contrast, the effects of candidate partisanship are substantial. Among Democrats, shifting a candidate's partisanship from Republican (the baseline) to Democrat increases the likelihood of selection by $10 \%$ points among donors $(\mathrm{SE}=0.0107)$ and $15 \%$ points among the public $(\mathrm{SE}=0.0130)$. Both estimates are statistically significant, as is the difference; the public leans on candidate partisanship more heavily than the donors. Across the aisle, the effect of candidate partisanship is similar among Republicans, although the difference in magnitude between the public and donors falls shy of statistical significance. Still, GOP donors and the public are $12 \%$ points $(\mathrm{SE}=0.0236)$ and $17 \%$ points $(\mathrm{SE}=0.0146)$, respectively, more likely to vote for a Republican relative to a Democrat.

The next two items test the effects of economic and social policy positions (taxes and racial discrimination) on candidate support. On taxes, moving from a less progressive to a more progressive stance increases Democrats' likelihood of supporting a candidate among both the public and donors (by 13\% points and 15\% points, respectively; SEs $=0.0153,0.0121$ ). For Republicans,

\footnotetext{
${ }^{8}$ One other point of clarification in interpreting AMCEs is necessary. Both Clayton, Ferwerda, and Horiuchi (2019) and Leeper, Hobolt, and Tilley (2019) note that comparing AMCEs among different subgroups of respondents is sensitive to the baseline attribute level chosen for the analysis. Because our main attributes of interest are dichotomous, however, we can confidently compare AMCEs across various respondent subgroups without baseline attribute choices affecting our results. The race attribute, which has three levels, is an exception, but the AMCEs for race across all respondent subgroups are so small that there are no discernible effects regardless of which level is used as the baseline.
} 
Figure 1: Conjoint-elicited candidate preferences among partisan donors and voters
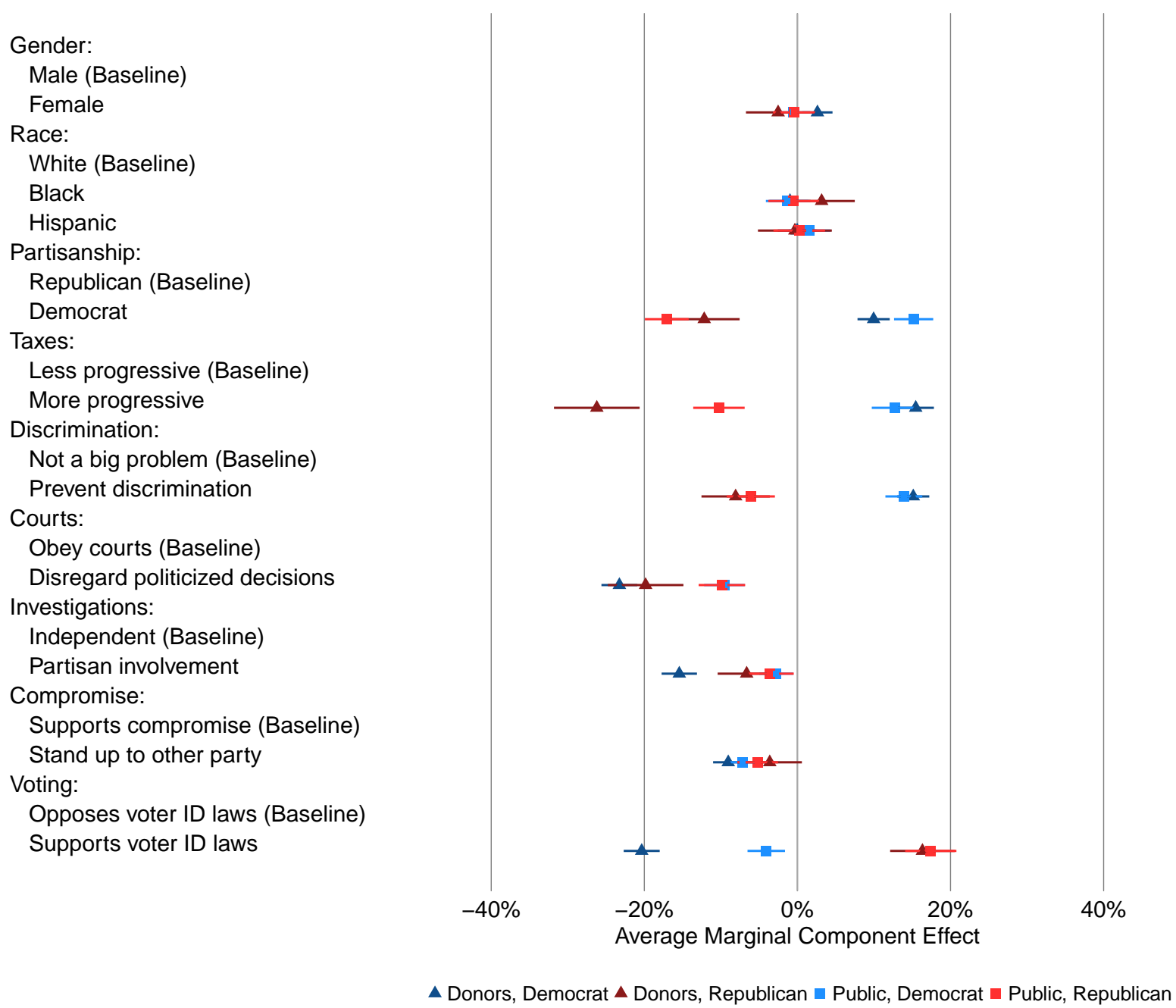

This figure shows the Average Marginal Component Effects of each attribute-level on the likelihood a candidate is selected, relative to a baseline level, among Democrats and Republicans in the donor and public samples. Colors indicate each respondent subsample. Standard errors are clustered by respondent.

more economically progressive candidates are $10 \%$ points $(\mathrm{SE}=0.0171)$ less likely to be selected in the public sample and $26 \%$ points less likely to be selected $(\mathrm{SE}=0.0285)$ by donors, the largest effect we observe. The effects of candidate social policy positions are similar between donors and the public. Moving from a more conservative to a more liberal stance on racial discrimination increases the probability of Democratic support by $14 \%$ points $(\mathrm{SE}=0.0123)$ among the public and $15 \%$ points $(\mathrm{SE}=0.0107)$ among donors, and decreases the probability of Republican support 
by $6 \%$ points $(\mathrm{SE}=0.0161)$ among the public and $8 \%$ points $(\mathrm{SE}=0.0228)$ among donors. ${ }^{9}$

We are most interested, however, in the effect of democratic norm violations on candidate support. Encouragingly, for judicial deference, impartial investigations, and willingness to compromise, we do not observe partisan splits like those described above. Each partisan and constituency group is more supportive of candidates who uphold these democratic principles and penalizes those who betray them.

First, the effects of candidates pledging to "obey the courts even when they think that the decisions are wrong" rather than saying "elected officials should not be bound by court decisions they regard as politicized" are positive for all groups. The effects of judicial deference on candidate support are greater among donors (23\% points for Democrats, $\mathrm{SE}=0.0120 ; 20 \%$ points for Republicans, $\mathrm{SE}=0.0252)$ than the public $(10 \%$ points among both Democrats and Republicans; SEs $=0.0135$ and 0.0155 , respectively). On average, protecting investigations of politicians and their associates from partisan influence also has positive effects. Among Democratic donors, the probability of support for a candidate who "said elected officials should supervise law enforcement investigations of politicians and their associates" is $15 \%$ points $(\mathrm{SE}=0.0118)$ lower than for one who maintained that such investigations "should be free of partisan influence." The effects of support for neutrality are weaker, but run in the same direction, among Republican donors (7\% points, $\mathrm{SE}=0.0193)$, Democrats in the public (3\% points, $\mathrm{SE}=0.0113)$, and Republicans in the public (4\% points, $\mathrm{SE}=0.0160)$. Finally, candidates who advocate "standing up to the other party" are penalized relative to those who promise to "work for compromise across party lines." The effects among Democrats (9\% points for donors, $\mathrm{SE}=0.0101 ; 7 \%$ points for public, $\mathrm{SE}=0.0109$ ) are slightly stronger than among Republicans (4\% points for donors, $\mathrm{SE}=0.0214 ; 5 \%$ points for public, $\mathrm{SE}=0.0136$ ), but we find no significant differences on compromise within either party.

In contrast, we find party polarization on ballot access, the most controversial attribute related to democratic principles and the only one that was directly linked to a policy proposal. The effects

\footnotetext{
${ }^{9}$ Although our experiments included fewer specific policy positions than Broockman and Malhotra (2018), the pattern we find matches theirs in that Republican donors are to the right of party identifiers and Democratic donors are to the left, particularly if we consider the voter ID finding described below to measure a policy preference.
} 
of candidates favoring "new legislation to require voters to show state-issued ID at the polls" on Republican public and donor support are substantial $(17 \%$ and $16 \%$ points, SEs $=0.0171$ and 0.0215, respectively). By contrast, the effects of voter ID support on candidate choice among Democrats are negative, although the magnitude is only comparable among donors (20\% points compared to $4 \%$ points for the public; SEs $=0.0120$ and 0.0125 , respectively).

To illustrate these marginal effects, we calculated predicted support probabilities for co-partisan candidates who violate shared democratic norms among the public. Among Democrats (Republicans), a white, male, Democratic (Republican) candidate who holds traditionally liberal (conservative) positions on discrimination, taxes, and ballot access ${ }^{10}$ and who does not transgress democratic norms on judicial deference, impartial investigations, or compromise, has an $84.0 \%(84.6 \%)$ chance of being selected. If he transgresses one norm, that likelihood drops to 73.6-80.2\% (74.9$80.4 \%$ ) depending on the norm in question. If he transgresses two norms, the likelihood of selection drops to between 66.2-72.8\% (69.7-75.2\%). Finally, if he transgresses all three democratic norms, the likelihood drops to $62.5 \%(65.4 \%)$. The equivalent marginal effects for donors (shown in the Online Appendix) are even larger than among the public, with net decreases in the likelihood of selection of $30-45 \%$ points when moving from zero to three violations of democratic principles.

Our results also provide evidence that democratic norm violations do not have diminishing marginal effects. We ran a linear regression model with indicators for whether a candidate violated one, two, or three of the aforementioned democratic norms and then separately estimated the marginal effect of one, two, or three norm violations (versus zero) on the likelihood of selection among Democrats and Republicans in the public and donor samples. The results, which are shown in Figure 2, indicate that the marginal effects of democratic norm violations are approximately linear, meaning that the marginal punishment for an additional norm violation is roughly constant as transgressions accumulate. We also find that the negative effects of norm violations on the likelihood of candidate choice are similar for Republicans and Democrats in the general public, greater

\footnotetext{
${ }^{10}$ We hold positions on ballot access fixed in line with the stance favored by each party because access to the ballot is the one democratic principle on which we found partisan polarization. We estimate the magnitude of punishment effects for transgressions of principles on which we found pro-democracy consensus across party lines only.
} 
in magnitude among Republican donors, and larger still among Democratic donors.

Figure 2: Norms violated and candidate choice among partisan donors and voters

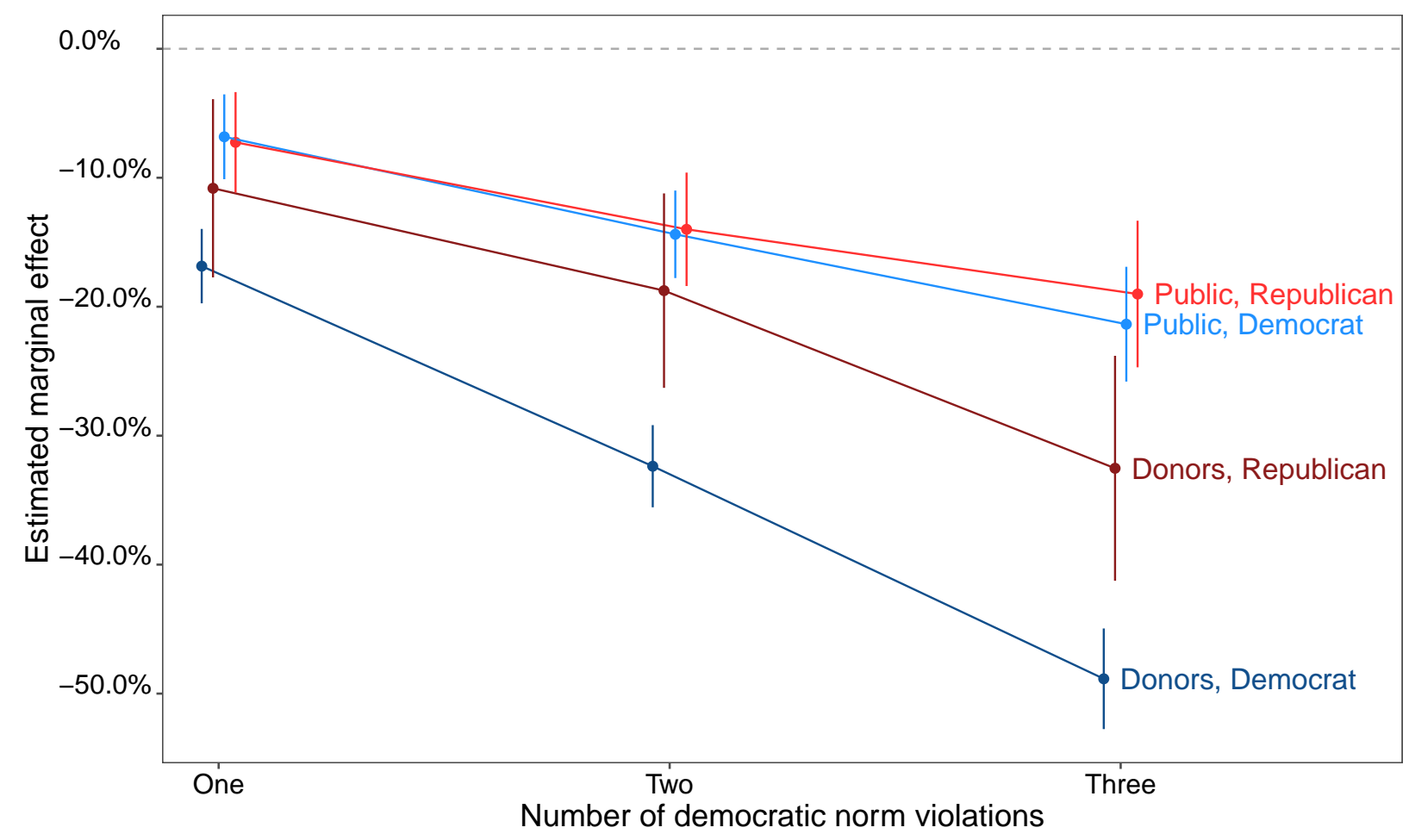

This figure shows the estimated marginal effects of one, two, or three norm violations (versus zero) on the likelihood that a candidate is selected. Colors indicate each respondent subsample. Standard errors are clustered by respondent. The model includes covariates for age, gender, and education level.

Finally, we find no evidence of interactions between respondent and candidate partisanship for democratic values. Partisans are not more willing to forgive transgressions by co-partisan candidates in either sample compared to opposition candidates. This finding holds for the principles of judicial deference, independent investigations, democratic compromise, and ballot access via opposition to voter ID laws (see the Online Appendix for details).

\section{Conclusion}

Our results provide both encouraging and sobering signals about democratic priorities. First, we find common ground across parties with regard to democratic transgressions that would undermine 
institutions of accountability and foreclose compromise. The effects of promising to respect court decisions, supporting investigations into wrongdoing, and advocating for compromise rather than confrontation across party lines on candidate support are all positive. Moreover, the positive effects of pro-democracy positions are greater among donors than the public, contradicting fears that elite donor influence necessarily undermines democracy (e.g., Mayer 2017), and not conditional on candidate partisanship.

We urge caution, however, in interpreting these seemingly encouraging findings. The effects of supporting politically impartial investigations are positive on average among both Democrats and Republicans, but conceptions of impartiality may differ across parties. For instance, partisans diverged widely in their approval of Robert Mueller's investigation prior to the release of his report (Mehta 2019). Indeed, previous research has found consensus between supporters and opponents of President Trump that public officials should be punished for malfeasance, but those groups may have different officials or types of wrongdoing in mind (Carey et al. 2019). Other research also indicates that people are more willing to punish opposition partisans than co-partisans for democratic norm violations (Svolik 2018; Graham and Svolik 2019); the lack of differential sanctions we find may be an exception to the rule. Moreover, politicians' specific transgressions against democratic principles may be more narrowly tailored, and thus appear more justifiable, than the broad statements tested in our study.

We also find troubling levels of partisan polarization on the key democratic value of equal voting rights, reflecting a fundamental division over who should be included in, or excluded from, the political community. The effects of supporting voter ID laws on candidate support are positive for Republicans and negative for Democrats. ${ }^{11}$ We find even greater polarization on this issue among top donors, who are much more divided than their parties' rank and file.

How do we explain these divergent results? One possibility is that the pattern is an artifact of our experimental design. According to this view, we may observe polarization only on support

\footnotetext{
${ }^{11}$ Though scholarly debate continues over the effect of voter ID laws on turnout, convincing evidence exists that racial and ethnic minorities are more likely than whites to lack the documentation such laws require. Moreover, the problem such laws ostensibly address-election fraud by voter impersonation-is exceedingly rare. See the Online Appendix for a review of the relevant research.
} 
for voter identification laws because it is the only attribute measuring a policy position rather than a broad statement of principle. Alternatively, however, the difference could be attributable to greater polarization among elites on voter fraud (e.g., Biggers and Hanmer 2017), which is the democratic principle we tested that has most direct implications for the parties at the ballot box. By contrast, the other democratic principles tested remain largely mainstream views that politicians on both sides endorse at least in principle (Zaller 1992). This latter interpretation is more worrisome because it suggests that each principle could become polarizing given sufficient partisan opposition or electoral incentives. Future research should seek to evaluate these competing interpretations and test how vulnerable currently uncontested democratic principles are to elite politicization. More generally, it would be valuable to test the effect of violations of other democratic norms in addition

to the four evaluated in this study (e.g., encouraging violence, using government power against the media, making false statements, etc.).

Ultimately, our results suggest that Americans do share a consensus on democratic principles regarding accountability and compromise. However, the parties are deeply divided on the core democratic value of broad and equal access to the vote, especially among donors. This divide over access to the franchise highlights a fundamental vulnerability in America's democratic consensus.

\section{References}

Abramson, Scott F., Korhan Koçak, and Asya Magazinnik. 2019. "What Do We Learn About Voter Preferences From Conjoint Experiments?" Working paper, available at: https://scholar.princeton.edu/sites/default/files/kkocak/files/conjoint_draft.pdf.

Ansolabehere, Stephen, and Eitan D. Hersh. 2017. “ADGN: An Algorithm for Record Linkage Using Address, Date of Birth, Gender, and Name.” Statistics and Public Policy 4(1): 1-10.

Barber, Michael J. 2016. "Representing the Preferences of Donors, Partisans, and Voters in the US Senate.” Public Opinion Quarterly 80(S1): 225-249. 
Barr, Andy. 2010. “The GOP's No-Compromise Pledge.” October 28. Politico. https://www.politico.com/story/2010/10/the-gops-no-compromise-pledge-044311. (Last Accessed: December 16, 2019).

Barreto, Matt A., Stephen Nuño, Gabriel R. Sanchez, and Hannah L. Walker. 2019. “The Racial Implications of Voter Identification Laws in America.” American Politics Research 47(2): 238-249.

Berelson, Bernard. 1952. "Democratic Theory and Public Opinion.” The Public Opinion Quarterly 16(3): 313-330.

Biggers, Daniel R., and Michael J. Hanmer. 2017. "Understanding the Adoption of Voter Identification Laws in the American States.” American Politics Research 45(4): 560-588.

Bonica, Adam, Nolan McCarty, Keith T Poole, and Howard Rosenthal. 2013. "Why Hasn’t Democracy Slowed Rising Inequality?” Journal of Economic Perspectives 27(3): 103-124.

Broockman, David, and Neil Malhotra. 2018. "What Do Donors Want? Heterogeneity by Party and Policy Domain." Working paper, avilable at SSRN: https://papers.ssrn.com/sol3/papers.cfm?abstract_id=3288862.

Burden, Barry C. 2018. "Disagreement over ID Requirements and Minority Voter Turnout.” The Journal of Politics 80(3): 1060-1063.

Butler, Daniel M., and Jonathan Homola. 2017. “An Empirical Justification for the Use of Racially Distinctive Names to Signal Race in Experiments.” Political Analysis 25(01): 122-130.

Carey, John M., Gretchen Helmke, Brendan Nyhan, Mitchell Sanders, and Susan C. Stokes. 2019. “Searching for Bright Lines in the Trump Presidency." Perspectives on Politics 17(3): 699-718.

Clayton, Katherine, Jeremy Ferwerda, and Yusaku Horiuchi. 2019. "Exposure to Immigration 
and Admission Preferences: Evidence from France.” Forthcoming, Political Behavior. Available at: https://doi.org/10.1007/s11109-019-09550-z.

Cottrell, David, Michael C. Herron, and Sean J. Westwood. 2018. “An Exploration of Donald Trump's Allegations of Massive Voter Fraud in the 2016 General Election.” Electoral Studies 51: $123-142$.

Fishkin, Joseph, and David E. Pozen. 2018. “Asymmetric Constitutional Hardball.” Columbia Law Review 118.

Foa, Roberto Stefan, and Yascha Mounk. 2016. “The Danger of Deconsolidation: The Democratic Disconnect." Journal of Democracy 27(3): 5-17.

Gerber, Alan A., Andrew Gooch, and Gregory A. Huber. 2017. 'Evaluations of Candidates' Non-policy Characteristics from Issue Positions: Evidence about Valence Spillover.” Working paper.

Gilens, Martin. 2012. Affluence and Influence: Economic Inequality and Political Power in America. Princeton, NJ: Princeton University Press.

Gilens, Martin, and Benjamin I Page. 2014. "Testing Theories of American Politics: Elites, Interest Groups, and Average Citizens.” Perspectives on Politics 12(3): 564-581.

Graham, Matthew, and Milan W. Svolik. 2019. "Democracy in America? Partisanship, Polarization, and the Robustness of Support for Democracy in the United States." Working paper, available at SSRN: https://papers.ssrn.com/sol3/papers.cfm?abstract_id=3354559.

Grimmer, Justin, Eitan Hersh, Marc Meredith, Jonathan Mummolo, and Clayton Nall. 2018. “Obstacles to Estimating Voter ID Laws' Effect on Turnout.” The Journal of Politics 80(3): 1045-1051.

Gutmann, Amy, and Dennis F. Thompson. 2012. The Spirit of Compromise: Why Governing Demands It and Campaigning Undermines It. Princeton, NJ: Princeton University Press. 
Habermas, Jiirgen. 1994. “Three Normative Models of Democracy.” Constellations 1(1): 1-10.

Hainmueller, Jens, Daniel J Hopkins, and Teppei Yamamoto. 2014. "Causal Inference in Conjoint Analysis: Understanding Multidimensional Choices via Stated Preference Experiments." Political Analysis 22(1): 1-30.

Hainmueller, Jens, Dominik Hangartner, and Teppei Yamamoto. 2015. "Validating Vignette and Conjoint Survey Experiments Against Real-World Behavior.” Proceedings of the National Academy of Sciences of the United States of America 112(8): 2395-400.

Hajnal, Zoltan, Nazita Lajevardi, and Lindsay Nielson. 2017. "Voter Identification Laws and the Suppression of Minority Votes." The Journal of Politics 79(2): 363-379.

Helmke, Gretchen, and Frances Rosenbluth. 2009. "Regimes and the Rule of Law: Judicial Independence in Comparative Perspective." Annual Review of Political Science 12(1): 345-366.

Hopkins, Daniel J., Marc Meredith, Michael Morse, Sarah Smith, and Jesse Yoder. 2017. "Voting But for the Law: Evidence from Virginia on Photo Identification Requirements." Journal of Empirical Legal Studies 14(1): 79-128.

Horiuchi, Yusaku, Zachary Markovich, and Teppei Yamamoto. 2020. "Does Conjoint Analysis Mitigate Social Desirability Bias?" MIT Political Science Department Research Paper No. 2018-15. Available at: https://papers.ssrn.com/sol3/papers.cfm?abstract_id=3219323.

Leeper, Thomas J, Sara B Hobolt, and James Tilley. 2019. "Measuring Subgroup Preferences in Conjoint Experiments." Forthcoming, Political Analysis. Available at: https://doi.org/10.1017/pan.2019.30.

Levitsky, Steven, and Daniel Ziblatt. 2018. How Democracies Die. New York, NY: Crown.

Levitt, Justin. 2007. "The Truth About Voter Fraud.” Brennan Center for Justice. Available at: http://www.brennancenter.org/sites/default/files/legacy/The Truth About Voter Fraud.pdf. 
Mason, Liliana. 2018. Uncivil Agreement: How Politics Became Our Identity. Chicago, IL: University of Chicago Press.

Mayer, Jane. 2017. Dark Money: The Hidden History of the Billionaires Behind the Rise of the Radical Right. New York, NY: Penguin Random House.

Mehta, Dhrumil. 2019. "Both Parties Think The Mueller Report Was Fair. They Just Completely Disagree On What It Says.” May 3. https://fivethirtyeight.com/features/both-parties-think-themueller-report-was-fair-they-just-disagree-on-what-it-says/. FiveThirtyEight. (Last Accessed: May 31, 2019).

Mikelionis, Luke. 2019. “Trump Urged To Ignore Supreme Court, Print Census Question: 'Because We Should,' GOP Lawmaker Says.” July 5. https://www.foxnews.com/politics/gopcongressman-trump-ignore-supreme-court-print-census-citizenship-question. Fox News. (Last Accessed: December 16, 2019).

Minnite, Lorraine C. 2010. The Myth of Voter Fraud. Ithaca, NY: Cornell University Press.

Mounk, Yascha. 2018. “We Haven’t Normalized Trump, We've Just Gotten Used to Him. That May be Worse.” January 17. https://slate.com/news-and-politics/2018/01/we-haventnormalized-trump-weve-just-gotten-used-to-him-that-may-be-worse.html. Slate. (Last Accessed: January 9, 2019).

Neiheisel, Jacob R., and Rich Horner. 2019. "Voter Identification Requirements and Aggregate Turnout in the U.S.: How Campaigns Offset the Costs of Turning Out When Voting Is Made More Difficult." Forthcoming at Election Law Journal: Rules, Politics, and Policy. Available at: https://www.liebertpub.com/doi/abs/10.1089/elj.2018.0500.

New Voting Restrictions in America. 2019. October 1. https://www.brennancenter.org/our-work/research-reports/new-voting-restrictions-america. Brennan Center for Justice. (Last Accessed: October 1, 2019). 
Pew Research Center. 2017. "The Partisan Divide on Political Values Grows Even Wider."

October 5. http://www.people-press.org/2017/10/05/the-partisan-divide-on-political-valuesgrows-even-wider/. Pew Research Center. (Last Accessed: June 13, 2019).

Rocha, Rene R., and Tetsuya Matsubayashi. 2014. "The Politics of Race and Voter ID Laws in the States: The Return of Jim Crow?” Political Research Quarterly 67(3): 666-679.

Sargent, Greg. 2018. An Uncivil War: Taking Back Our Democracy in an Age of Trumpian Disinformation and Thunderdome Politics. New York, NY: HarperCollins Publishers.

Siegel, Benjamin, and Alisa Wiersema. 2017. “GOP Congressman Demands Mueller Firing: It's Time 'To Put Up or Shut Up'.” December 15. https://abcnews.go.com/Politics/gopcongressman-demands-mueller-firing-time-put-shut/story?id=51814557. ABC News. (Last Accessed: December 16, 2019).

Svolik, Milan W. 2018. "When Polarization Trumps Civic Virtue: Partisan Conflict and the Subversion of Democracy by Incumbents.” Working paper, available at: https://pdfs.semanticscholar.org/4d2c/50628b3333c52e6f0c7488cae125a996b3f3.pdf.

V-Dem. 2018. “Democracy for All?” The V-Dem Annual Democracy Report 2018. Available at: https://www.v-dem.net/en/news/democracy-all-v-dem-annual-democracy-report-2018/.

Valentino, Nicholas A, and Fabian G Neuner. 2017. "Why the Sky Didn’t Fall: Mobilizing Anger in Reaction to Voter ID Laws.” Political Psychology 38(2): 331-350.

Voeten, Erik. 2016. “Are People Really Turning Away from Democracy?” Journal of Democracy Web Exchange. Available at: https://www.journalofdemocracy.org/wpcontent/uploads/2018/12/Journal-of-Democracy-Web-Exchange-Voeten_0.pdf.

Weingast, Barry R. 1997. "The Political Foundations of Democracy and the Rule of the Law." American Political Science Review 91(02): 245-263. 
Wike, Richard, and Janell Fetterolf. 2018. “Liberal Democracy's Crisis of Confidence.” Journal of Democracy 29(4): 136-150.

Zaller, John R. 1992. The Nature and Origins of Mass Opinion. New York: Cambridge University Press. 


\section{Online Appendix}

\section{Who Will Defend Democracy? Evaluating Tradeoffs in Candidate Support Among Partisan Donors and Voters}

\section{The conjoint experiment}

\section{Attributes and levels}

In the experiments, each candidate was described using eight characteristics: name, partisanship, positions on policies toward taxation and racial discrimination, and four positions reflecting democratic values. The characteristics of the candidates were randomly generated from the following sets of alternatives:

- Name (gender and race/ethnicity): Each candidate was assigned a name from a list of 123 names designed to signal both gender (man or woman) and race/ethnicity (either white, black, or Hispanic) (see Butler and Homola 2017).

- Partisanship: Democrat or Republican.

- Policy positions: The surveys included two attributes reflecting salient party differences over policy — one on taxation, the other on racial discrimination (see Bartels 2018).

- Taxation

* Wants to raise taxes on the wealthy.

* Wants to lower taxes on everyone, including the wealthy.

- Racial discrimination

* Believes the government should do more to prevent discrimination against racial minorities.

* Believes discrimination against racial minorities is less of a problem now than in the past.

- Democratic values: The surveys included four attributes related to core democratic values.

- Judicial deference

* Said elected officials must obey the courts even when they think that the decisions are wrong.

* Said elected officials should not be bound by court decisions they regard as politicized.

- Investigations/rule of law

* Said law enforcement investigations of politicians and their associates should be free of partisan influence.

* Said elected officials should supervise law enforcement investigations of politicians and their associates.

- Compromise

* Promises to work for compromise across party lines.

* Promises to stand up to the other party. 
- Voting rights/access

* Opposes new legislation to require voters to show state-issued ID at the polls.

* Supports new legislation to require voters to show state-issued ID at the polls.

\section{Justification}

Our candidate profiles were designed to force respondents to make trade-offs between demographic characteristics, partisanship, policy positions, and democratic values. Below we provide justification for the attributes we chose to include.

We used candidate names to signal gender and race/ethnicity for a number of reasons. First, using names increases realism. Second, using a name to signal both gender and race/ethnicity is economical in terms of space in the survey instrument. Finally, using names reduces concerns about social desirability bias in survey responses while still allowing us to estimate how gender and race/ethnicity affect preferences between candidates (for example, Broockman 2013; DeSante 2013; White, Nathan, and Faller 2015; Doherty, Dowling, and Miller 2018).

Partisanship is the predominant driver of American political behavior (Campbell et al. 1960) and as such is frequently tested in many candidate choice experiments in political science (e.g., Carnes and Lupu 2016; Horiuchi, Smith, and Yamamoto 2018; Ono and Burden 2018; see also Kirkland and Coppock 2018). Since third party lawmakers are extremely rare in the U.S. federal government, we only offered Democrat and Republican as options for partisanship.

We also gave our candidates two positions on policy that divide sharply across party lines. Bartels (2018) finds that limited government and cultural conservatism are the political and social views that are most polarizing between Democrats and Republicans, so we included attributes reflecting positions on each of these items. We note that since the attributes and levels in the experiment were randomly generated, it was possible for some unlikely combinations to be generated (i.e., a Republican who supports raising taxes on the wealthy). However, we elected to allow for all possible attribute-level combinations to appear in order to analyze the causal quantities involving all possible combinations (Hainmueller, Hopkins, and Yamamoto 2014, p. 9).

Finally, we assigned candidate positions on four issues related to democratic principles. Modern democracy is inherently multi-dimensional; there are of course numerous principles that one might consider. In this study, we sought to choose principles that were both salient in contemporary politics and relevant to research on democratic erosion. The four specific principles are support for or opposition to judicial deference (an essential component of the rule of law); impartial investigations (a key check on abuses of power and impunity that was especially salient before the release of special counsel Robert Mueller's report); compromise (an important governing value); and ballot access (a critical component of democratic equality, which we proxy using support for voter identification laws). We discuss the justification for the selection of these principles further in the main text. 


\section{Example conjoint table}

Figure A1 shows an illustrative example of a conjoint table seen by participants.

Figure A1: Sample conjoint table used in experiment

Suppose the two individuals below are candidates in an upcoming election.

\begin{tabular}{|c|c|}
\hline Candidate 1 & Candidate 2 \\
\hline Hannah Phillips & Luis Vasquez \\
\hline Democrat & Republican \\
party. & $\begin{array}{c}\text { Promises to stand up to the other } \\
\text { party. }\end{array}$ \\
\hline $\begin{array}{c}\text { Paid elected officials should supervise } \\
\text { law enforcement investigations of } \\
\text { politicians and their associates. }\end{array}$ & $\begin{array}{c}\text { Said law enforcement investigations } \\
\text { of politicians and their associates } \\
\text { should be free of partisan influence. }\end{array}$ \\
\hline $\begin{array}{c}\text { Said elected officials should not be } \\
\text { bound by court decisions they regard } \\
\text { as politicized. }\end{array}$ & $\begin{array}{c}\text { Said elected officials must obey the } \\
\text { courts even when they think that the } \\
\text { decisions are wrong. }\end{array}$ \\
\hline $\begin{array}{c}\text { Believes discrimination against racial } \\
\text { minorities is less of a problem now } \\
\text { than in the past. }\end{array}$ & $\begin{array}{c}\text { Believes the government should do } \\
\text { more to prevent discrimination against } \\
\text { racial minorities. }\end{array}$ \\
\hline $\begin{array}{c}\text { Opposes new legislation to require } \\
\text { voters to show state-issued ID at the } \\
\text { polls. }\end{array}$ & $\begin{array}{c}\text { Opposes new legislation to require } \\
\text { voters to show state-issued ID at the } \\
\text { polls. }\end{array}$ \\
\hline Wants to lower taxes on everyone, \\
including the wealthy.
\end{tabular}$\quad$\begin{tabular}{c} 
Wants to raise taxes on the wealthy. \\
\hline
\end{tabular}

Based on the information above, which of the following two candidates would you be more likely to support?

Candidate $1 \quad$ Candidate 2 


\section{Samples}

\section{Recruitment of donor sample}

We drew inspiration from Broockman and Malhotra (2018) to recruit a sample of campaign donors to our survey. The sample comes from publicly available Federal Election Commission data on U.S. campaign donors. These data are maintained for research use online in the Database on Ideology, Money in Politics, and Elections (DIME). Several of the datasets in this database include individual-level data on the names and addresses of all campaign donors in election cycles since 1980. Using data on all campaign contributions in the 2016 election cycle, we identified individuals in the top $1 \%$ for total amount donated to federal election campaigns. We then drew a random sample of 20,000 donors from the top $1 \%$ by total giving to the party to which they gave the most. ${ }^{1}$ The median total contribution to federal campaigns in 2016 by individuals we invited to participate in our survey was $\$ 5,400$; the mean was $\$ 8,076.17$; the minimum was $\$ 3,500$; and the maximum was $\$ 645,400$. Among this sample, $59 \%$ donated to one or more Democratic candidates, $40 \%$ donated to one or more Republican candidates, and $1 \%$ donated to some other candidate or campaign.

We created a letter inviting people to participate in our survey that provided instructions for how to access it online. Specifically, the letter told potential participants that they had been selected at random from publicly available lists of people who participate in democracy, and directed them to a website at which they could follow a link to take the online survey. Each letter was addressed to each potential participant by name, and included a unique access code that the participant had to enter in order to take the survey after following the link at the website. ${ }^{2}$ These access codes were not retained in our survey data, which ensures the anonymity of our responses. Note that this precludes us from knowing the total amount donated by individuals who took our survey or the partisanship of the recipients of their donations.

Partnering with a company that prints and distributes commercial and non-profit mail, we sent the letters to our 20,000 donors at the addresses listed in the dataset. The letters were dropped at the post office on March 15, 2019, and we closed the survey on April 17, 2019.

We collected a total of 570 responses, for a response rate of about $6 \%$. We kept all responses for which respondents had evaluated at least one conjoint table. 533 respondents $(5.3 \%)$ completed the entire survey, a response rate that is comparable to the 7\% observed by Broockman and Malhotra (2018).

\footnotetext{
${ }^{1}$ We grouped individuals by a unique identifier included in the DIME dataset, the party to which they donated, their name, and their address. In order to avoid sending multiple letters to a small percentage of individuals who gave to both parties, had multiple addresses listed under the same unique identifier, or had multiple spellings of their name under the same unique identifier, our sample includes only individuals who made donations at the same address to one party and are listed under the same name.

${ }^{2}$ Approximately half of the individuals who followed this link were sent to a different, unrelated survey we conducted simultaneously with this one; hence, we calculated response rates by dividing the total number of responses by 10,000 , rather than 20,000 .
} 


\section{Sample descriptive statistics}

Table A1: Summary statistics, donor and public samples (1)

Characteristic $\quad$ Donors $(n=570) \quad$ Public $(n=954)$

Age

$18-24$

25-34

$0.2 \%$

$12.8 \%$

$35-44$

$1.2 \%$

$17.3 \%$

45-54

$4.0 \%$

$14.9 \%$

$55-64$

$16.1 \%$

$13.1 \%$

65-74

$26.8 \%$

$21.4 \%$

75-84

$35.4 \%$

$14.5 \%$

$14.2 \%$

$5.1 \%$

85 or older

$1.9 \%$

$1.0 \%$

Sex

Male

$60.3 \%$

$48.0 \%$

Female

$39.7 \%$

$52.0 \%$

Education

Did not graduate from high school

$0.0 \%$

$6.9 \%$

High school diploma or the equivalent (GED)

$1.1 \%$

$31.8 \%$

Some college

$4.0 \%$

$22.8 \%$

Associate's degree

$1.6 \%$

$9.9 \%$

Bachelor's degree

$26.5 \%$

$18.6 \%$

Master's degree

$24.8 \%$

$6.6 \%$

Professional or doctorate degree

$42.0 \%$

$3.4 \%$

Race

White

$91.0 \%$

$65.3 \%$

Black or African American

$0.7 \%$

$11.6 \%$

American Indian or Alaska Native

$0.4 \%$

$1.2 \%$

Asian/Pacific Islander

$2.3 \%$

$2.4 \%$

Multi-racial

$1.6 \%$

$2.8 \%$

Hispanic/Latino/Chicano/a

$1.9 \%$

$14.7 \%$

Other

$2.1 \%$

$2.0 \%$

Note: The distribution for the public sample includes survey weights implemented by YouGov. The matched cases were weighted to the sampling frame using propensity scores. 
Table A2: Summary statistics, donor and public samples (2)

Characteristic

Party

Republican

Democrat

Neither

\section{Ideology}

Conservative

Moderate

Liberal
$19.7 \%$

$75.7 \%$

$4.6 \%$

$18.5 \%$

$11.1 \%$

$70.5 \%$

$19.1 \%$

$80.9 \%$

$84.6 \%$

$15.1 \%$

$0.4 \%$

$0.0 \%$
$34.5 \%$

$49.4 \%$

$16.1 \%$

$38.6 \%$

$30.7 \%$

$30.7 \%$

$43.9 \%$

$56.1 \%$

$52.0 \%$

$29.5 \%$

$13.5 \%$

$4.9 \%$

Note: The distribution for the public sample includes survey weights implemented by YouGov. The matched cases were weighted to the sampling frame using propensity scores. For partisanship, the estimates include partisan leaners. 


\section{Tests of preregistered hypotheses: Spring 2019}

We conducted an initial conjoint candidate choice experiment in October 2018 on a representative sample of the American public that did not include donors. Before fielding that study, we preregistered a set of hypotheses related to trade-offs among partisanship, policy positions, and democratic values at EGAP (ID: BLINDED FOR REVIEW). The core hypotheses were that respondents would favor candidates who uphold each democratic principle included in the survey and disfavor candidates who betray them. We also posited that respondents' partisanship would be a stronger driver of voting preference than any of the four democratic principles included in the survey. We describe all of our hypotheses in more detail below. When we replicated the same candidate choice experiment with another representative public sample and a sample of elite donors to federal campaigns in March 2019 (the results of which we describe in the main text of the paper), we did not preregister separate hypotheses for the new sample. Below we first report the results of these hypothesis tests for the March 2019 public sample and then provide analogous results for the October 2018 public sample.

\section{Main effects}

Our first hypotheses concern voters' commitment to candidates who violate democratic norms. We offer a series of competing hypotheses about the effects of democratic norm transgressions versus stances that defend democracy on voters' support of candidates. We then describe the theoretical rationale behind these hypotheses and report whether they were supported in our data.

- Hypothesis 1a. Respondents are less likely to choose a candidate who said elected officials should supervise investigations than one who said investigations should be free from partisan influence.

- Hypothesis $1 b$. Respondents are more likely to choose a candidate who said elected officials should supervise investigations than one who said investigations should be free from partisan influence.

- Hypothesis $2 a$. Respondents are less likely to choose a candidate who supports voter ID laws than one who opposes such laws.

- Hypothesis $2 b$. Respondents are more likely to choose a candidate who supports voter ID laws than one who opposes such laws.

- Hypothesis 3a. Respondents are less likely to choose a candidate who promises to stand up to the other party than one who promises to work for compromise.

- Hypothesis $3 b$. Respondents are more likely to choose a candidate who promises to stand up to the other party than one who promises to work for compromise.

- Hypothesis 4a. Respondents are less likely to choose a candidate who said elected officials should not be bound by court decisions they regard as politicized than one who said elected officials must obey the courts even when they think that the decisions are wrong.

- Hypothesis $4 b$. Respondents are more likely to choose a candidate who said elected officials should not be bound by court decisions they regard as politicized than one who said elected officials must obey the courts even when they think that the decisions are wrong.

A wide body of literature suggests that Americans are opposed to democratic norm violations. Drutman, Diamond, and Goldman (2018a) find that large majorities of Americans do not agree 
with the statements that Congress should not oversee the president, that the media should not scrutinize the president, and that the president should not be bound by the laws or courts. However, the effect of undemocratic platforms on vote choice may be small. Drutman, Diamond, and Goldman (2018a) find that only 54\% of Americans are supportive of all five metrics of democracy presented to them in a survey. In a conjoint experiment, Graham and Svolik (2019) find that when a candidate adopts an undemocratic platform, he or she loses about $10 \%$ of the overall vote share.

On the other hand, some literature suggests that there is popular support for platforms that experts regard as democratic norm transgressions. A Gallup poll found that $80 \%$ of Americans support voter ID laws, which suggests that they are not widely regarded as a democratic transgression among the American people (McCarthy 2016). Claims that elected officials can or should be involved in law enforcement investigations have been increasingly widespread in the context of Robert Mueller's investigation of Russian involvement in the 2016 election (Holland, Mason, and Oliphant 2018), and around 30\% of Americans supported Trump's decision to fire FBI director James Comey (Shepard 2017). Finally, a 2018 Pew study found that over half of Americans prefer politicians who stick to their positions while $44 \%$ prefer politicians who make compromises (prior to 2018 , the majority of the public preferred compromise).

The results of our hypothesis tests are described below:

- H1a is supported. Respondents are $4.0 \%$ points ( $\mathrm{SE}=0.0081)$ less likely to choose a candidate who said elected officials should supervise law enforcement investigations of politicians and their associates than one who said such investigations should be free from partisan influence.

- $\mathrm{H} 2 \mathrm{~b}$ is supported. Respondents are 5.3\% ( $\mathrm{SE}=0.0093)$ points more likely to choose a candidate who supports voter ID laws than one who opposes voter ID laws.

- H3a is supported. Respondents are $6.4 \%(\mathrm{SE}=0.0076)$ points less likely to choose a candidate who promises to stand by their party than one who promises to work for compromise across party lines.

- $\mathrm{H} 4 \mathrm{a}$ is supported. Respondents are $10.6 \%(\mathrm{SE}=0.0084)$ points less likely to choose a candidate who said elected officials should not be bound by court decisions they regard as politicized than one who said elected officials must obey the courts even when they think that the decisions are wrong.

\section{Differences in marginal effects between attributes}

We also test how partisanship and two policy positions (regarding cultural conservatism and limited government) impact candidate support. We propose two (non-competing) hypotheses regarding the effect of each on support of a candidate, relative to the effects of platforms related to democratic values.

- Hypothesis 5a. Among each partisan group, the partisanship attribute has a larger impact on respondents' likelihood of choosing a candidate than any of the four democracy attributes.

- Hypothesis 5b. Among each partisan group, each of the policy attributes has a larger impact on respondents' likelihood of choosing a candidate than any of the four democracy attributes.

Graham and Svolik (2019) find that the (relative) weight of upholding democratic values is about $7.6 \%$, compared to $92.4 \%$ that is given to partisan and policy considerations. Notably, however, they are unable to discern whether partisanship or specific economic and social policies drive 
vote choice. Svolik (2018) finds that Venezuelan voters are willing to support a candidate who violates democratic norms when the candidate's economic policies appeal to their interests.

The results of our hypothesis tests are as follows:

- H5a is partially supported. For Republicans, the absolute value of the AMCE for partisanship is larger than the absolute values of the AMCEs for three of the four democracy attributes, and for Democrats, the absolute value of the AMCE for partisanship is larger than the absolute values of the AMCEs for any of the four democracy attributes. Specifically, among Republicans, the AMCE for partisanship is -0.171 ( $\mathrm{SE}=0.0146$ ); that is, a Democratic candidate is $17.1 \%$ points less likely to be selected than a Republican candidate. The absolute values of the AMCEs for the democracy attributes among Republicans range from -0.036 to 0.174 , or $3.6 \%$ points to $17.4 \%$ points. Notably, the AMCE for the voting rights attribute is larger than that for partisanship among Republicans, which suggests that support of voter ID laws is a stronger predictor of candidate support than is partisanship for Republicans. Among Democrats, the AMCE for partisanship is 0.152 ( $\mathrm{SE}=0.0139)$; that is, a Democratic candidate is $15.2 \%$ points more likely to be selected than a Republican candidate. The absolute values of the AMCEs for the democracy attributes among Democrats range from -0.028 to -0.095 , or $2.8 \%$ points to $9.5 \%$ points.

- H5b is supported for Democrats, but not supported for Republicans. The absolute values of the AMCEs for the two policy attributes are larger than the absolute values of the AMCEs for each of the four democracy attributes among Democrats, but smaller among Republicans. For Democrats, the AMCE for discrimination is 0.139 ( $\mathrm{SE}=0.0123$ ) and that for taxes is 0.127 ( $\mathrm{SE}=0.0153$ ); that is, a candidate who said the government should protect racial minorities from discrimination is $13.9 \%$ points more likely to be selected than one who said discrimination is less of a problem today than in the past, and a candidate who wants to raise taxes on the wealthy is $12.7 \%$ points more likely to be selected than one who wants to raise taxes on everyone, including the wealthy. The absolute values of the AMCEs for the democracy attributes among Democrats range from 0.028 to 0.095 , or $2.8 \%$ points to $9.5 \%$ points. For Republicans, on the other hand, the AMCE for discrimination is $-0.061(6.1 \%$ points, $\mathrm{SE}=0.0161)$ and that for taxes is $-0.103(10.3 \%$ points, $\mathrm{SE}=0.0171)$, while the absolute values of the AMCEs for all of the democracy attributes range from 0.036 to 0.174 , or $3.6 \%$ points to $17.4 \%$ points.

\section{Heterogeneous effects}

Voters may be more likely to forgive transgressions against democratic values by co-partisan candidates than opposition party candidates. However, popular support for voter ID laws and American attitudes towards compromise in particular suggest that some of the democracy platforms that experts regard as norm transgressions may be perceived favorably by the general public. We specify three sets of competing hypotheses testing the general claim that the effect of the democracy attributes on candidate support will be greater for candidates from the other party than for co-partisans.

- Hypothesis 6a. Among each partisan group, the impact of supporting voter ID laws (relative to opposing voter ID laws) is larger for opposition party candidates than for co-partisan candidates. 
- Hypothesis 6b. Among each partisan group, the impact of supporting voter ID laws (relative to opposing voter ID laws) is smaller for opposition party candidates than for co-partisan candidates.

- Hypothesis 7a. Among each partisan group, the impact of supporting elected officials' supervision of investigations (relative to supporting elections that are free from partisan influence) is larger for opposition party candidates than for co-partisan candidates.

- Hypothesis 7b. Among each partisan group, the impact of supporting elected officials' supervision of investigations (relative to supporting investigations that are free from partisan influence) is smaller for opposition party candidates than for co-partisan candidates.

- Hypothesis 8a. Among each partisan group, the impact of standing up to the other party (relative to working for compromise) is larger for opposition party candidates than for copartisan candidates

- Hypothesis $8 b$. Among each partisan group, the impact of standing up to the other party (relative to working for compromise) is smaller for opposition party candidates than for copartisan candidates.

- Hypothesis 9a. Among each partisan group, the impact of saying elected officials should not be bound by court decisions they regard as politicized (relative to saying elected officials must obey the courts even when they think their decisions are wrong) is larger for opposition party candidates than for co-partisan candidates.

- Hypothesis $9 b$. Among each partisan group, the impact of saying elected officials should not be bound by court decisions they regard as politicized (relative to saying elected officials must obey the courts even when they think their decisions are wrong) is smaller for opposition party candidates than for co-partisan candidates.

Graham and Svolik (2019) find that Americans are unlikely to prioritize democratic platforms when doing so goes against their partisan, ideological, or policy preferences; specifically, they are more likely to choose a proximate candidate (in terms of party, ideology, or policy preferences) with an undemocratic platform than a more distant candidate with a democratic platform. They also find that voters punish undemocratic candidates more severely when the candidates are from the opposing party. Svolik (2018) finds similar results in a conjoint experiment conducted in Venezuela. More broadly, literature on partisan motivated reasoning suggests that people interpret new information through the lens of their partisan identity (e.g., Bolsen, Druckman, and Cook 2014; Lavine, Johnston, and Steenberger 2012). Our experiment's prime on partisanship may stimulate partisan motivated reasoning. Still, Bullock (2011) finds that although party cues are influential determinants of policy preferences, partisans are often affected as least as much (or more) by policy information; even if partisanship attenuates the effects of undemocratic platforms, they may not be completely disregarded.

The results of these hypothesis tests are shown below:

- H6a and H6b are not supported. Among both Democratic and Republican respondents, the difference in likelihood of selecting an opposition party candidate who supports voter ID laws versus a co-partisan candidate who supports voter ID laws is not significant.

- H7a and H7b are not supported. Among both Democratic and Republican respondents, the difference in likelihood of selecting an opposition party candidate who supports elected officials' supervision of investigations (relative to supporting investigations that are free from partisan influence) versus a co-partisan candidate with the same stance is not significant.

- H8a and H8b are not supported. Among both Democratic and Republican respondents, the 
difference in likelihood of selecting an opposition party candidate who promises to stand up to the other party (relative to one who promises to work for compromise) vs. a co-partisan candidate with the same stance is not significant.

- H9a and H9b are not supported. Among both Democratic and Republican respondents, the difference in likelihood of selecting an opposition party candidate who said elected officials should not be bound by court decisions they regard as politicized (relative to saying elected officials must obey the courts even when they think their decisions are wrong) versus a copartisan candidate with the same stance is not significant.

We also test whether responses to democratic transgressions differ among members of one party over another. Specifically, we offer three non-competing hypotheses regarding Republicans' vs. Democrats' views toward candidates who transgress democratic values:

- Hypothesis 10. Republicans/Trump approvers are more likely to choose a candidate who supports voter ID laws (relative to one who opposes such laws) than Democrats/Trump disapprovers.

- Hypothesis 10b. Republicans/Trump approvers are more likely to choose a candidate who said elected officials should supervise investigations (relative to one who said investigations should be free from partisan influence) than Democrats/Trump disapprovers.

- Hypothesis 10c. Republicans/Trump approvers are more likely to choose a candidate who promises to stand up to the other party (relative to one who promises to work for compromise) than Democrats/Trump disapprovers.

- Hypothesis 10d. Republicans/Trump approvers are more likely to choose a candidate who said elected officials should not be bound by court decisions they regard as politicized (relative to one who said elected officials must obey the courts even when they think their decisions are wrong) than Democrats/Trump disapprovers.

Drutman, Diamond, and Goldman (2018a) find that support for a strong leader is significantly higher among conservatives than liberals, and conservatives show higher agreement with the statement that democracy is not always preferable. This is particularly true among cultural conservatives. They also find that people who supported Donald Trump in the 2016 presidential primaries are most open to authoritarian political systems, including strong leaders and army rule. Drutman, Diamond, and Goldman (2018b) find that Trump approvers are much more likely to show preferences for less accountability and oversight.

The results are as follows:

- H10a is supported. Among Republicans (Trump approvers), a candidate who supports voter ID laws is $17.4 \%$ points $(17.8 \%$ points, $\mathrm{SE}=0.0171)$ more likely to be selected than one who opposes such laws. Among Democrats, a candidate who supports voter ID laws is $4.1 \%$ points $(3.8 \%$ points, $\mathrm{SE}=0.0125$ ) less likely to be selected than one who opposes such laws. The difference in estimates between Republicans and Democrats (Trump approvers and Trump disapprovers) is significant at the 0.05 level.

- H10b is not supported. There is no significant difference between Republicans/Trump approvers and Democrats/Trump disapprovers in terms of likelihood of selecting a candidate who said elected officials should supervise investigations (relative to one who said investigations should be free from partisan influence).

- H10c is not supported. There is no significant difference between Republicans/Trump approvers and Democrats/Trump disapprovers in terms of likelihood of selecting a candidate who promises to stand up to the other party (relative to one who promises to work for com- 
promise).

- H1dc is not supported. There is no significant difference between Republicans/Trump approvers and Democrats/Trump disapprovers in terms of likelihood of selecting a candidate who said elected officials should not be bound by court decisions they regard as politicized (relative to one who said elected officials must obey the courts even when they think their decisions are wrong).

We now turn to heterogeneous effects according to other respondent characteristics. We offer a series of hypotheses about differences in candidate preferences by education level and political knowledge, and by political interest:

- Hypothesis 11a. Less educated respondents are more likely to choose a candidate who supports voter ID laws (relative to one who opposes such laws) than more educated respondents.

- Hypothesis $11 b$. Less educated respondents are more likely to choose a candidate who said elected officials should supervise investigations (relative to one who said investigations should be free from partisan influence) than more educated respondents.

- Hypothesis 11c. Less educated respondents are more likely to choose a candidate who promises to stand up to the other party (relative to one who promises to work for compromise) than more educated respondents.

- Hypothesis 11d. Less educated respondents are more likely to choose a candidate who said elected officials should not be bound by court decisions they regard as politicized (relative to one who said elected officials must obey the courts even when they think their decisions are wrong) than more educated respondents.

- Hypothesis 12a. Low political knowledge respondents are more likely to choose a candidate who supports voter ID laws (relative to one who opposes such laws) than high political knowledge respondents.

- Hypothesis $12 b$. Low political knowledge respondents are more likely to choose a candidate who said elected officials should supervise investigations (relative to one who said investigations should be free from partisan influence) than high political knowledge respondents.

- Hypothesis 12c. Low political knowledge respondents are more likely to choose a candidate who promises to stand up to the other party (relative to one who promises to work for compromise) than high political knowledge respondents.

- Hypothesis $12 d$. Low political knowledge respondents are more likely to choose a candidate who said elected officials should not be bound by court decisions they regard as politicized (relative to one who said elected officials must obey the courts even when they think their decisions are wrong) than high political knowledge respondents.

Drutman, Diamond, and Goldman (2018b) find that support for democracy is weakest among the least educated. Specifically, more education is associated with lower support for a "strong leader" and lower agreement with the statement that "democracy is not always preferable." Drutman, Diamond, and Goldman (2018a) find that among Trump approvers, more educated people express lower agreement with the statements that Congress should not oversee the president, that the media should not scrutinize the president, and that the president should not be bound by the laws or courts. Twenge, Carter, and Campbell (2015) find that higher education is associated with greater tolerance.

- Hypothesis 13a. Less politically interested respondents are more likely to choose a candidate who supports voter ID laws (relative to one who opposes such laws) than more politically interested respondents. 
- Hypothesis $13 b$. Less politically interested respondents are more likely to choose a candidate who said elected officials should supervise investigations (relative to one who said investigations should be free from partisan influence) than more politically interested respondents.

- Hypothesis $13 \mathrm{c}$. Less politically interested respondents are more likely to choose a candidate who promises to stand up to the other party (relative to one who promises to work for compromise) than more politically interested respondents.

- Hypothesis $13 d$. Less politically interested respondents are more likely to choose a candidate who said elected officials should not be bound by court decisions they regard as politicized (relative to one who said elected officials must obey the courts even when they think their decisions are wrong) than more politically interested respondents.

Drutman, Diamond, and Goldman (2018b) also find that support for democracy is weakest among the least politically interested. High politically interested people are less supportive of a strong leader and express stronger preferences for democracy. Drutman, Diamond, and Goldman (2018a) find that among Trump approvers, high politically interested people express lower agreement with the statements that Congress should not oversee the president, that the media should not scrutinize the president, and that the president should not be bound by the laws or courts.

The results of our hypothesis tests are below:

- H11a is supported. Among respondents with a bachelor's degree or higher, a candidate who supports voter ID laws is $2.0 \%$ ( $\mathrm{SE}=0.0199$ ) points more likely to be selected than one who opposes voter ID laws. Among respondents with lower than a bachelor's degree, a candidate who supports voter ID laws is $7.0 \%$ ( $\mathrm{SE}=0.0116)$ points more likely to be selected than one who opposes voter ID laws. While both estimates are in the same direction, the difference in estimates between more and less educated respondents is significant at the 0.05 level.

- H11b is supported. Among respondents with a bachelor's degree or higher, a candidate who said elected officials should supervise investigations is $6.3 \%$ points $(\mathrm{SE}=0.0148)$ less likely to be selected than one who said investigations should be free from partisan influence. Among respondents with lower than a bachelor's degree, a candidate who said elected officials should supervise investigations is $2.2 \%$ points $(\mathrm{SE}=0.0105)$ less likely to be selected than one who said investigations should be free from partisan influence. While both estimates are in the same direction, the difference in estimates between more and less educated respondents is significant at the 0.05 level.

- H11c is not supported. There is no significant difference between more and less educated respondents in terms of likelihood of selecting a candidate who promises to stand up to the other party (relative to one who promises to work for compromise).

- H11d is supported. Among respondents with a bachelor's degree or higher, a candidate who said elected officials should not be bound by court decisions they regard as politicized is $14.6 \%$ points $(\mathrm{SE}=0.0168)$ less likely to be selected than one who said elected officials must obey the courts even when they think their decisions are wrong. Among respondents with lower than a bachelor's degree, a candidate who said elected officials should not be bound by court decisions they regard as politicized is $8.8 \%$ points $(\mathrm{SE}=0.0109)$ less likely to be selected than one who said elected officials must obey the courts even when they think their decisions are wrong. While both estimates are in the same direction, the difference in estimates between more and less educated respondents is significant at the 0.05 level.

- H12a is not supported. There is no significant difference between more and less politically knowledgeable respondents in terms of likelihood of selecting a candidate who supports 
vs. opposes voter ID laws.

- H12b is supported. Among high political knowledge respondents, a candidate who said elected officials should supervise investigations is $6.8 \%$ points $(\mathrm{SE}=0.0110)$ less likely to be selected than one who said investigations should be free from partisan influence. Among low political knowledge respondents, a candidate who said elected officials should supervise investigations is $0.8 \%$ points $(\mathrm{SE}=0.0142)$ less likely to be selected than one who said investigations should be free from partisan influence, and this estimate is not significant from zero. The difference in estimates between more and less politically knowledgeable respondents is significant at the 0.05 level.

- H12c is supported. Among respondents with high political knowledge, a candidate who promises to stand up to the other party is $8.0 \%$ points $(\mathrm{SE}=0.0109)$ less likely to be selected than one who promises to work for compromise. Among respondents with low political knowledge, a candidate who promises to stand up to the other party is $4.2 \%$ points ( $\mathrm{SE}=$ 0.0121) less likely to be selected than one who promises to work for compromise. While both estimates are in the same direction, the difference in estimates between more and less politically knowledgeable respondents is significant at the 0.05 level.

- H12d is supported. Among respondents with high political knowledge, a candidate who said elected officials should not be bound by court decisions they regard as politicized is $14.0 \%$ points $(\mathrm{SE}=0.0125)$ less likely to be selected than one who said elected officials must obey the courts even when they think their decisions are wrong. Among respondents with low political knowledge, a candidate who said elected officials should not be bound by court decisions they regard as politicized is $6.1 \%$ points $(\mathrm{SE}=0.0141)$ less likely to be selected than one who said elected officials must obey the courts even when they think their decisions are wrong. While both estimates are in the same direction, the difference in estimates between more and less politically knowledgeable respondents is significant at the 0.05 level.

- H13a is not supported. There is no significant difference between more and less politically interested respondents in terms of likelihood of selecting a candidate who supports vs. opposes voter ID laws.

- H13b is supported. More politically interested respondents are less likely to choose a candidate who said elected officials should supervise investigations (relative to one who said investigations should be free from partisan influence) than more politically interested respondents. Among more politically interested respondents, a candidate who said elected officials should supervise investigations is $6.2 \%$ points $(\mathrm{SE}=0.0123$ ) less likely to be selected than one who said investigations should be free from partisan influence. Among less politically interested respondents, a candidate who said elected officials should supervise investigations is $0.5 \%$ points $(\mathrm{SE}=0.0121)$ less likely to be selected than one who said investigations should be free from partisan influence, and this estimate is not significant from zero. While both estimates are in the same direction, the difference in estimates between more and less politically interested respondents is significant at the 0.05 level.

- H13c is not supported. There is no significant difference between more and less politically interested respondents in terms of likelihood of selecting a candidate who promises to stand up to the other party (relative to one who promises to work for compromise).

- H13d is not supported. There is no significant difference between more and less politically interested respondents in terms of likelihood of selecting a candidate who said officials 
should not be bound by court decisions they regard as politicized (relative to one who said elected officials must obey the courts even when they think their decisions are wrong).

Next, we offer a series of research questions about how "cross-pressured partisans" (i.e., Democrats who approve of Donald Trump or Republicans who disapprove of Donald Trump) react to specific democratic transgressions.

- Research question 1a. Are Republicans who disapprove of Donald Trump less likely to choose a candidate who supports voter ID laws (relative to one who opposes such laws) than Republicans who approve of Donald Trump?

- Research question $1 \mathrm{~b}$. Are Democrats who approve of Donald Trump more likely to choose a candidate who said elected officials should supervise investigations (relative to one who said investigations should be free from partisan influence) than Democrats who disapprove of Donald Trump?

- Research question 1c. Are Democrats who approve of Donald Trump more likely to choose a candidate who promises to stand up to the other party (relative to one who promises to work for compromise) than Democrats who disapprove of Donald Trump?

The investigations attribute is a personal cue to Donald Trump. Outside this context, there may not be an inherently partisan difference on how much people value the independence of investigations. Both sets of "cross-pressured partisans" may differ from their co-partisans on investigations, with Trump-disapproving-Republicans supporting independence (relative to other Republicans) and Trump-approving-Democrats opposing independence (relative to other Democrats). With regard to the elections attribute, to the extent that Trump-approving-Democrats fit the narrative as lower-educated, economically vulnerable, white working class, "traditional" Democratic voters, they might be less opposed to racially targeted voter suppression laws than is the party mainstream.

The answers to our research questions are as follows:

- There is no significant difference between Republicans who approve of Donald Trump and those who disapprove of Donald Trump in terms of likelihood of selecting a candidate who supports voter ID laws (relative to one who opposes such laws).

- There is no significant difference between Democrats who approve of Donald Trump and those who disapprove of Donald Trump in terms of likelihood of selecting a candidate who said elected officials should supervise investigations (relative to one who said investigations should be free from partisan influence).

- There is no significant difference between Democrats who approve of Donald Trump and those who disapprove of Donald Trump in terms of likelihood of selecting a candidate who promises to stand up to the other party (relative to who promises to work for compromise).

Finally, we have three research questions about how preferences regarding democratic values vary by respondents' age.

- Research Question 2a. Are older respondents less likely to choose a candidate who supports voter ID laws (relative to one who opposes such laws) than younger respondents?

- Research Question $2 b$. Are older respondents less likely to choose a candidate who said elected officials should supervise investigations (relative to one who said investigations should be free from partisan influence) than younger respondents?

- Research Question 2c. Are older respondents less likely to choose a candidate who promises to stand up to the other party (relative to one who promises to work for compromise) than younger respondents?

- Research Question 2d. Are older respondents less likely to choose a candidate who said 
elected officials should not be bound by court decisions they regard as politicized (relative to one who said elected officials must obey the courts even when they think their decisions are wrong)?

Foa and Mounk (2016) find that millennials are more cynical about the value of democracy as a political system, less hopeful that anything they do might influence public policy, and more willing to express support for authoritarian alternatives. Voeten (2016) argues that American millennials are somewhat more skeptical of democracy than young people were twenty years ago, but also shows that older generations have less faith in American democratic institutions. Drutman, Diamond, and Goldman (2018b) find that young respondents are less likely than older ones to say they prefer democracy, but they also show weaker preferences for a "strong leader." In a separate vein of research on tolerance, Twenge, Carter, and Campbell (2015) find that Americans have become more tolerant over time, but people born in the late 1940s (Boomers) are the most tolerant when age and time period are controlled.

The answers to our research questions are as follows:

- There is no significant difference between older and younger respondents in terms of likelihood of selecting a candidate who supports voter ID laws (relative to one who opposes voter ID laws).

- There is no significant difference between older and younger respondents in terms of likelihood of selecting a candidate who said elected officials should supervise investigations (relative to one who said investigations should be free from partisan influence).

- There is no significant difference between older and younger respondents in terms of likelihood of selecting a candidate who promises to stand up to the other party (relative to one who promises to work for compromise).

- There is no significant difference between older and younger respondents in terms of likelihood of selecting a candidate who said elected officials should not be bound by court decisions they regard as politicized (relative to one who said elected officials must obey the courts even when they think their decisions are wrong).

\section{Tests of preregistered hypotheses: October 2018}

We present the results of the hypothesis tests for our October 2018 public sample. Our findings are largely identical to those presented above; for differences, see H8a, H11a, H12c, H13d, RQ1a, and RQ2a.

\section{Main effects}

- H1a is supported. Respondents are $5.2 \%$ points $(\mathrm{SE}=0.0081)$ less likely to choose a candidate who said elected officials should supervise law enforcement investigations of politicians and their associates than one who said such investigations should be free from partisan influence.

- $\mathrm{H} 2 \mathrm{~b}$ is supported. Respondents are $3.4 \%$ points $(\mathrm{SE}=0.0093)$ more likely to choose a candidate who supports voter ID laws than one who opposes voter ID laws. 
- $\mathrm{H} 3 \mathrm{a}$ is supported. Respondents are $6.6 \%$ points $(\mathrm{SE}=0.0081)$ less likely to choose a candidate who promises to stand by their party than one who promises to work for compromise across party lines.

- $\mathrm{H} 4 \mathrm{a}$ is supported. Respondents are $10.6 \%$ points $(\mathrm{SE}=0.0083)$ less likely to choose a candidate who said elected officials should not be bound by court decisions they regard as politicized than one who said elected officials must obey the courts even when they think that the decisions are wrong.

\section{Differences in marginal effects between attributes}

- H5a is partially supported. For Republicans, the absolute value of the AMCE for partisanship is larger than the absolute values of the AMCEs for three of the four democracy attributes, and for Democrats, the absolute value of the AMCE for partisanship is larger than the absolute values of the AMCEs for any of the four democracy attributes. Specifically, among Republicans, the AMCE for partisanship is -0.190 ( $\mathrm{SE}=0.0155)$; that is, a Republican candidate is $19.0 \%$ points more likely to be selected than a Democratic candidate. The absolute values of the AMCEs for the democracy attributes among Republicans range from 0.037 to 0.166 , or $3.7 \%$ points to $16.6 \%$ points. Notably, the AMCE for the voting attribute is larger than that for partisanship among Republicans, which suggests that support of voter ID laws is a stronger predictor of candidate support than is partisanship for Republicans. Among Democrats, the AMCE for partisanship is 0.189 ( $\mathrm{SE}=0.0137$ ); that is, a Republican candidate is $18.9 \%$ points less likely to be selected than a Democratic candidate. The absolute values of the AMCEs for the democracy attributes among Democrats range from 0.053 to 0.097 , or $5.3 \%$ points to $9.7 \%$ points.

- H5b is supported for Democrats, but not supported for Republicans. The absolute values of the AMCEs for the two policy attributes are larger than the absolute values of the AMCEs for each of the four democracy attributes among Democrats, but smaller among Republicans. For Democrats, the AMCE for discrimination is 0.131 ( $\mathrm{SE}=0.0122)$ and that for taxes is 0.115 ( $\mathrm{SE}=0.0128$ ); that is, a candidate who said the government should protect racial minorities from discrimination is $13.1 \%$ points more likely to be selected than one who said discrimination is less of a problem today than in the past, and a candidate who wants to raise taxes on the wealthy is $11.5 \%$ points more likely to be selected than one who wants to raise taxes on everyone, including the wealthy. The absolute values of the AMCEs for the democracy attributes among Democrats range from 0.053 to 0.097 , or $5.3 \%$ points to 9.7\% points. For Republicans, on the other hand, the AMCE for discrimination is 0.037 (3.7\% points, $\mathrm{SE}=0.0135)$ and that for taxes is $0.089(8.9 \%$ points, $\mathrm{SE}=0.0158)$, while the absolute values of the AMCEs for all of the democracy attributes range from 0.037 to 0.166 , or $3.7 \%$ points to $16.6 \%$ points.

- H6a and H6b are not supported. Among both Democratic and Republican respondents, the difference in likelihood of selecting an opposition party candidate who supports voter ID laws vs. a co-partisan candidate who supports voter ID laws is not significant.

- H7a and H7b are not supported. Among both Democratic and Republican respondents, the difference in likelihood of selecting an opposition party candidate who supports elected officials' supervision of investigations (relative to supporting investigations that are free from 
partisan influence) vs. a co-partisan candidate with the same stance is not significant.

- H8a is partially supported, and H8b is not supported. Republican respondents are $10.0 \%$ points $(\mathrm{SE}=0.0179)$ less likely to select a Democratic candidate who promises to stand up to the other party (relative to one who promises to work for compromise). However, there is no significant difference between their likelihood of selecting a Republican candidate who promises to stand up to the other party (relative to one who promises to work for compromise). The difference between these two estimates is significant at the 0.05 level. Among Democratic respondents, the difference in likelihood of selecting a Republican candidate who promises to stand up to the other party (relative to one who promises to work for compromise) vs. a Democratic candidate with the same stance is not significant. H9a and H9b are not supported. Among both Democratic and Republican respondents, the difference in likelihood of selecting an opposition party candidate who said elected officials should not be bound by court decisions they regard as politicized (relative to saying elected officials must obey the courts even when they think their decisions are wrong) vs. a co-partisan candidate with the same stance is not significant.

\section{Heterogeneous effects}

- H10a is supported. Among Republicans (Trump approvers), a candidate who supports voter ID laws is $16.6 \%$ points $(\mathrm{SE}=0.0146)(17.1 \%$ points, $\mathrm{SE}=0.0130)$ more likely to be selected than one who opposes such laws. Among Democrats, a candidate who supports voter ID laws is $9.0 \%$ points $(\mathrm{SE}=0.0125)(6.6 \%$ points, $\mathrm{SE}=0.0111)$ less likely to be selected than one who opposes such laws. The difference in estimates between Republicans and Democrats (Trump approvers and Trump disapprovers) is significant at the 0.05 level.

- H10b is not supported. There is no significant difference between Republicans/Trump approvers and Democrats/Trump disapprovers in terms of likelihood of selecting a candidate who said elected officials should supervise investigations (relative to one who said investigations should be free from partisan influence).

- H10c is not supported. There is no significant difference between Republicans/Trump approvers and Democrats/Trump disapprovers in terms of likelihood of selecting a candidate who promises to stand up to the other party (relative to one who promises to work for compromise).

- H10d is not supported. There is no significant difference between Republicans/Trump approvers and Democrats/Trump disapprovers in terms of likelihood of selecting a candidate who said elected officials should not be bound by court decisions they regard as politicized (relative to one who said elected officials must obey the courts even when they think their decisions are wrong).

- H11a is not supported. There is no significant difference between more and less educated respondents in terms of likelihood of selecting a candidate who supports vs. opposes voter ID laws.

- H11b is supported. Among respondents with a bachelor's degree or higher, a candidate who said elected officials should supervise investigations is $8.8 \%$ points ( $\mathrm{SE}=0.0142$ ) less likely to be selected than one who said investigations should be free from partisan influence. Among respondents with lower than a bachelor's degree, a candidate who said elected offi- 
cials should supervise investigations is $3.7 \%$ points $(\mathrm{SE}=0.0098)$ less likely to be selected than one who said investigations should be free from partisan influence. While both estimates are in the same direction, the difference in estimates between more and less educated respondents is significant at the 0.05 level.

- H11c is not supported. There is no significant difference between more and less educated respondents in terms of likelihood of selecting a candidate who promises to stand up to the other party (relative to one who promises to work for compromise).

- H11d is supported. Among respondents with a bachelor's degree or higher, a candidate who said elected officials should not be bound by court decisions they regard as politicized is $14.5 \%$ points $(\mathrm{SE}=0.0162)$ less likely to be selected than one who said elected officials must obey the courts even when they think their decisions are wrong. Among respondents with lower than a bachelor's degree, a candidate who said elected officials should not be bound by court decisions they regard as politicized is $9.0 \%$ points ( $\mathrm{SE}=0.0096$ ) less likely to be selected than one who said elected officials must obey the courts even when they think their decisions are wrong. While both estimates are in the same direction, the difference in estimates between more and less educated respondents is significant at the 0.05 level.

- H12a is not supported. There is no significant difference between more and less politically knowledgeable respondents in terms of likelihood of selecting a candidate who supports vs. opposes voter ID laws.

- H12b is supported. Among high political knowledge respondents, a candidate who said elected officials should supervise investigations is $7.8 \%(\mathrm{SE}=0.0109)$ points less likely to be selected than one who said investigations should be free from partisan influence. Among low political knowledge respondents, a candidate who said elected officials should supervise investigations is $1.3 \%$ ( $\mathrm{SE}=0.0122$ ) points less likely to be selected than one who said investigations should be free from partisan influence, and this estimate is not significant from zero. The difference in estimates between more and less politically knowledgeable respondents is significant at the 0.05 level.

- H12c is not supported. There is no significant difference between more and less politically knowledgeable respondents in terms of likelihood of selecting a candidate who promises to stand up to the other party (relative to one who promises to work for compromise).

- H12d is supported. Among respondents with high political knowledge, a candidate who said elected officials should not be bound by court decisions they regard as politicized is $13.5 \%$ points $(\mathrm{SE}=0.0114$ ) less likely to be selected than one who said elected officials must obey the courts even when they think their decisions are wrong. Among respondents with low political knowledge, a candidate who said elected officials should not be bound by court decisions they regard as politicized is 6.2\% ( $\mathrm{SE}=0.0123)$ points less likely to be selected than one who said elected officials must obey the courts even when they think their decisions are wrong. While both estimates are in the same direction, the difference in estimates between more and less politically knowledgeable respondents is significant at the 0.05 level.

- H13a is not supported. There is no significant difference between more and less politically interested respondents in terms of likelihood of selecting a candidate who supports vs. opposes voter ID laws.

- H13b is supported. More politically interested respondents are less likely to choose a candidate who said elected officials should supervise investigations (relative to one who said 
investigations should be free from partisan influence) than more politically interested respondents. Among more politically interested respondents, a candidate who said elected officials should supervise investigations is $7.7 \%$ points $(\mathrm{SE}=0.0109)$ less likely to be selected than one who said investigations should be free from partisan influence. Among less politically interested respondents, a candidate who said elected officials should supervise investigations is $2.3 \%$ ( $\mathrm{SE}=0.0119$ ) points less likely to be selected than one who said investigations should be free from partisan influence. While both estimates are in the same direction, the difference in estimates between more and less politically interested respondents is significant at the 0.05 level.

- H13c is not supported. There is no significant difference more and less politically interested respondents in terms of likelihood of selecting a candidate who promises to stand up to the other party (relative to one who promises to work for compromise).

- H13d is supported. More politically interested respondents are less likely to choose a candidate who said officials should not be bound by court decisions they regard as politicized (relative to one who said elected officials must obey the courts even when they think their decisions are wrong) than less politically interested respondents. Among more politically interested respondents, a candidate who said elected officials should not be bound by court decisions they regard as politicized is $12.4 \%(\mathrm{SE}=0.0115)$ points less likely to be selected than one who said elected officials must obey the courts even when they think their decisions are wrong. Among less politically interested respondents, a candidate who said elected officials should not be bound by court decisions they regard as politicized is $8.5 \%$ points (SE $=0.0120$ ) less likely to be selected than one who said elected officials must obey the courts even when they think their decisions are wrong. The difference in estimates between more and less politically interested respondents is significant at the 0.05 level.

- RQ1a: Among Republicans who disapprove of Donald Trump, the difference in likelihood of selection for a candidate who supports vs. opposes voter ID laws $(2.5 \%$ points, SE $=$ 0.0301) is not significant from zero. Among Republicans who approve of Donald Trump, a candidate who supports voter ID laws is $18.6 \%$ points $(\mathrm{SE}=0.0157$ ) more likely to be selected (relative to one who opposes such laws). The difference between the two groups is significant at the 0.05 level.

- RQ1b: There is no significant difference between Democrats who approve of Donald Trump and those who disapprove of Donald Trump in terms of likelihood of selecting a candidate who said elected officials should supervise investigations (relative to one who said investigations should be free from partisan influence).

- RQ1c: There is no significant difference between Democrats who approve of Donald Trump and those who disapprove of Donald Trump in terms of likelihood of selecting a candidate who promises to stand up to the other party (relative to who promises to work for compromise).

- RQ2a: Among older respondents, a candidate who supports voter ID laws is $6.5 \%$ points $(\mathrm{SE}=0.0135)$ more likely to be selected (relative to one who opposes such laws). Among younger respondents, the difference in likelihood of selection for a candidate who supports vs. opposes voter ID laws $(0.3 \%$ points, $\mathrm{SE}=0.0125)$ is not significant from zero. The difference between the two groups is significant at the 0.05 level.

- RQ2b: There is no significant difference between older and younger respondents in terms of likelihood of selecting a candidate who said elected officials should supervise investigations 
(relative to one who said investigations should be free from partisan influence).

- RQ2c: There is no significant difference between older and younger respondents in terms of likelihood of selecting a candidate who promises to stand up to the other party (relative to one who promises to work for compromise).

- RQ2d: There is no significant difference between older and younger respondents in terms of likelihood of selecting a candidate who said elected officials should not be bound by court decisions they regard as politicized (relative to one who said elected officials must obey the courts even when they think their decisions are wrong). 


\section{Additional results}

\section{Comparing the public and donors by party}

The following two figures show preferences among Republicans (Figure A2) and Democrats (Figure A3) in the public (left panel) and donor (middle panel) samples, and the differences between them (right panel). Differences that are significant at the 0.05 level are highlighted in black; otherwise, the estimates are shown in gray. We describe the significant differences between our public and donor samples below.

Compared to Republicans in the public sample, Republicans in the donor sample are more strongly opposed to candidates who favor raising taxes on the wealthy than candidates with a more progressive stance. Among Republican donors, a more progressive candidate is $26.2 \%$ points (SE $=0.0285$ ) less likely to be selected than a less progressive candidate. Among Republicans in the public sample, a more progressive candidate is $10.3 \%$ points ( $\mathrm{SE}=0.0171$ ) less likely to be selected. The difference between the two groups, $15.9 \%$ points, is significant at the 0.05 level $(\mathrm{SE}=0.0333)$. We also observe a significant difference between the Republican public and donor samples on the democracy attribute related to judicial deference. Republican donors are $19.8 \%$ points $(\mathrm{SE}=0.0252)$ less likely to select a candidate who would disregard court decisions he or she regards as politicized than one who would obey the courts, while Republicans in the general public are $9.9 \%$ points $(\mathrm{SE}=0.0155)$ less likely to select said candidate. The $10 \%$ point difference $(\mathrm{SE}=0.0296)$ is significant at the 0.05 level.

Democrats show more significant differences between the public and donor samples. Democratic donors are more likely to select a female candidate than a male candidate $(2.6 \%$ points, SE $=0.0101)$ compared to their counterparts in the general public, for whom the estimate on gender is not significantly different from zero. The difference between the two groups, $3.1 \%$ points (SE $=0.0151$ ), is significant at the 0.05 level. Somewhat surprisingly, Democrats in the public sample weigh partisanship as more important than do Democratic donors; they are $15.2 \%$ points $(\mathrm{SE}=$ 0.0130) more likely to select a Democrat than a Republican. Democrats in the donor sample are only $10.0 \%$ points $(\mathrm{SE}=0.0107$ ) more likely to select a Democrat than a Republican, yielding a significant difference of $5.2 \%$ points $(\mathrm{SE}=0.0169)$.

The effects of candidates eschewing democratic norm violations are greater for Democratic donors than Democrats in the public sample. For the courts, Democrats in the donor sample are $23.3 \%$ points $(\mathrm{SE}=0.0120$ ) less likely to select a candidate who would disregard politicized court decisions. Among the Democrats in the public sample, the analogous estimate is $9.5 \%$ points (SE $=0.0135)$, and the difference between the two groups $(13.7 \%$ points, $\mathrm{SE}=0.0181)$ is significant at the 0.05 level. On the investigations attribute, Democratic donors are $15.4 \%$ points $(\mathrm{SE}=0.0118)$ less likely to choose a candidate who supports partisan involvement in investigations than one who favors independent investigations, compared to a $2.8 \%$ point $(\mathrm{SE}=0.0113)$ lower likelihood of selection among Democrats in the general public. Again, the difference between the two groups $(12.7 \%$ points, $\mathrm{SE}=0.0163)$ is significant at the 0.05 level. Finally, on the voting rights attribute, Democrats in the donor sample are more strongly opposed to candidates who support voter ID laws than Democrats in the public sample. Democratic donors are $20.3 \%$ points $(\mathrm{SE}=0.0120)$ less likely to choose a candidate who supports than opposes voter ID laws, while Democrats in the general public are just $4.1 \%$ points $(\mathrm{SE}=0.0125)$ less likely to choose said candidate. The $16.3 \%$ 
point $(\mathrm{SE}=0.0173)$ difference between the two groups is significant at the 0.05 level.

Figure A2: Preferences among public vs. donors, Republicans only

\section{Comparing Republican Public vs. Donors}

Gender:
Male (Baseline)
Female
Race:
White (Baseline)
Black
Hispanic
Partisanship:
Republican (Baseline)
Democrat
Taxes:
Less progressive (Baseline)
More progressive
Discrimination:
Not a big problem (Baseline)
Prevent discrimination
Courts:
Obey courts (Baseline)
Disregard politicized decisions
Investigations:
Independent (Baseline)
Partisan involvement
Compromise:
Supports compromise (Baseline)
Stand up to other party
Voting:
Opposes voter ID laws (Baseline)
Supports voter ID laws
$\begin{aligned} & \text { (n) } \\ & \text { (n) }\end{aligned}$


Figure A3: Preferences among public vs. donors, Democrats only

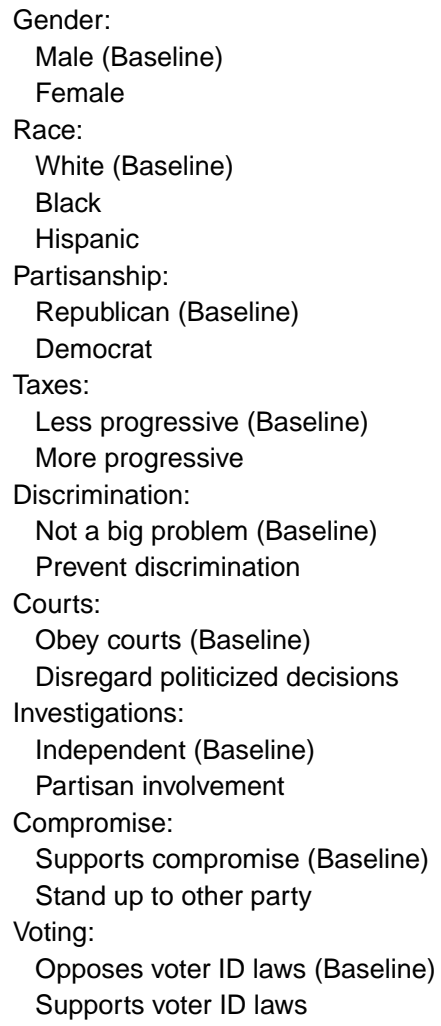

\section{Comparing Democratic Public vs. Donors}

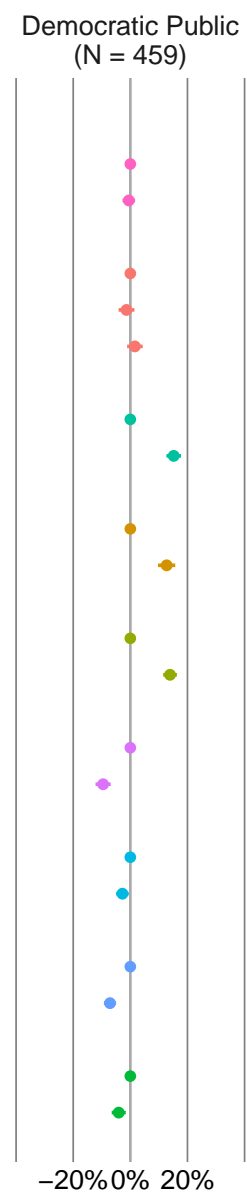

Democratic Donors

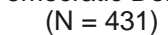

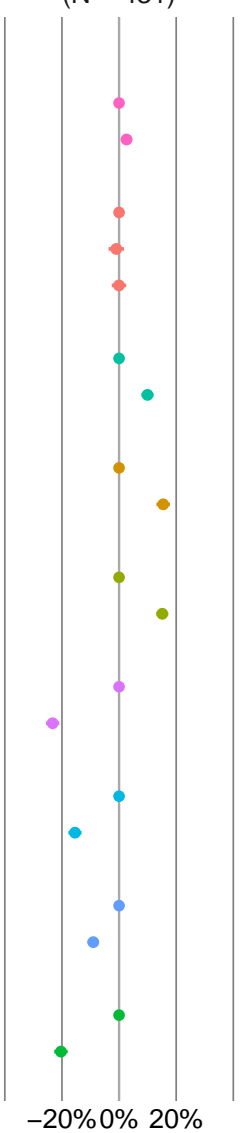

$-20 \% 0 \% 20 \%$

Average Marginal Component Effect
Difference

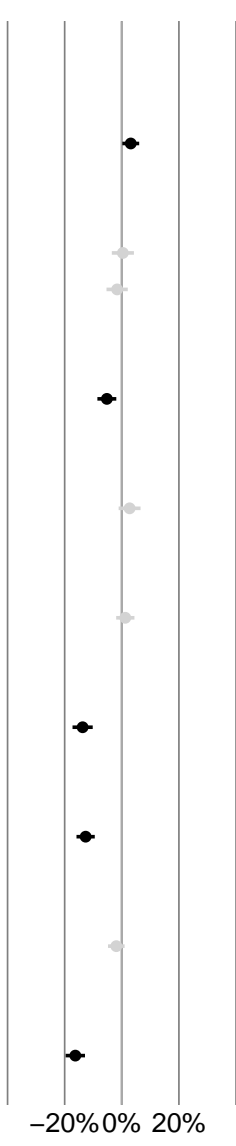




\section{Testing for differences in candidate evaluation by party}

As we describe briefly in our tests of Hypotheses 6 through 9 for the public sample, we are interested in not only respondents' absolute preferences for candidates who hold various positions on key democratic values, but also whether they are willing to forgive transgressions of democratic norms by co-partisan candidates (and not opposition party candidates). In the following four figures, we subset our data into four groups by sample and party (Republicans in the public [Figure A4], Republican donors [Figure A5], Democrats in the public [Figure A6], and Democratic donors [Figure A7]). We then run a model that excludes the candidate partisanship attribute and estimate preferences across all other attributes (gender, race/ethnicity, two policy positions, and four positions on democratic values) for Republican candidates (left panels) and Democratic candidates (middle panels). Differences are shown in the right panels, with any that are significant at the 0.05 highlighted in black, and insignificant differences shown in gray.

As the figures show, we find almost no evidence that respondents in any sample evaluate Republican and Democratic candidates differently. For Republicans in the public and donor samples, and Democrats in the public sample, there are no significant differences whatsoever in their likelihood of selecting Republican vs. Democratic candidates with various positions on any other attribute. For Democrats in the donor sample, we find a single significant difference, whereby Democratic donors punish Republican candidates who promise to "stand up to the other party" rather than "work for compromise across party lines" more severely than they do Democrats. Among these respondents, a Republican candidate who disfavors compromise is $11.2 \%$ points $(\mathrm{SE}=0.0138)$ less likely to be selected than a Republican who makes compromise a priority, while a Democrat who rebukes compromise is $6.8 \%$ points $(\mathrm{SE}=0.0143)$ less likely to be selected. The difference, $4.4 \%$ points $(\mathrm{SE}=0.0120)$, is significant at the 0.05 level. 
Figure A4: Preferences among Republicans (public) for Republican vs. Democratic candidates

\section{Republicans evaluate Republican vs. Democratic candidates (public)}

Gender:

Male (Baseline)

Female

Race:

White (Baseline)

Black

Hispanic

Discrimination:

Not a big problem (Baseline)

Prevent discrimination

Taxes:

Less progressive (Baseline)

More progressive

Voting:

Opposes voter ID laws (Baseline)

Supports voter ID laws

Courts:

Obey courts (Baseline)

Disregard politicized decisions

Investigations:

Independent (Baseline)

Partisan involvement

Compromise:

Supports compromise (Baseline)

Stand up to other party

Republican candidates

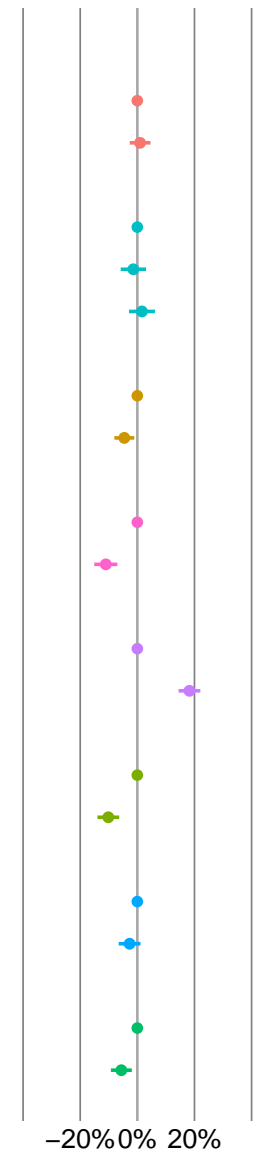

Democratic candidates

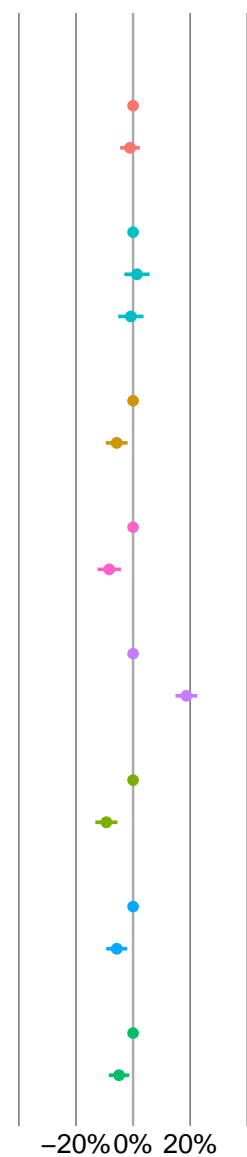

Difference

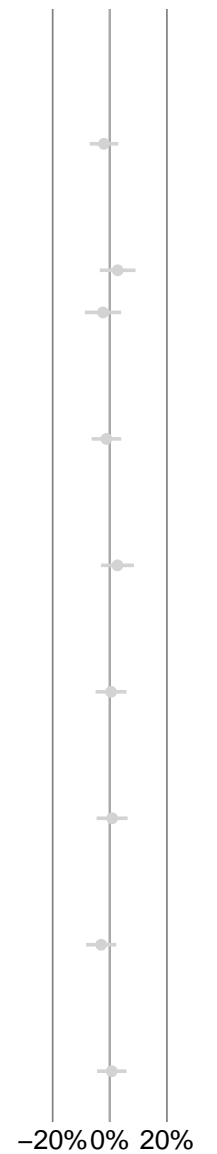

Average Marginal Component Effect 
Figure A5: Preferences among Republicans (donors) for Republican vs. Democratic candidates

\section{Republicans evaluate Republican vs. Democratic candidates (donors)}

Gender:

Male (Baseline)

Female

Race:

White (Baseline)

Black

Hispanic

Discrimination:

Not a big problem (Baseline)

Prevent discrimination

Taxes:

Less progressive (Baseline)

More progressive

Voting:

Opposes voter ID laws (Baseline)

Supports voter ID laws

Courts:

Obey courts (Baseline)

Disregard politicized decisions

Investigations:

Independent (Baseline)

Partisan involvement

Compromise:

Supports compromise (Baseline)

Stand up to other party

Republican candidates

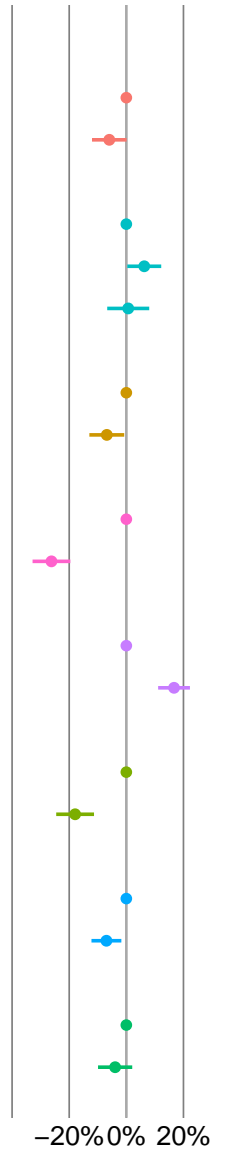

Democratic candidates

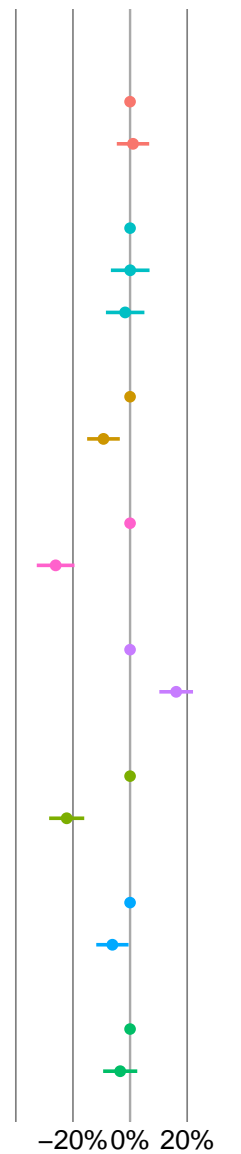

Difference

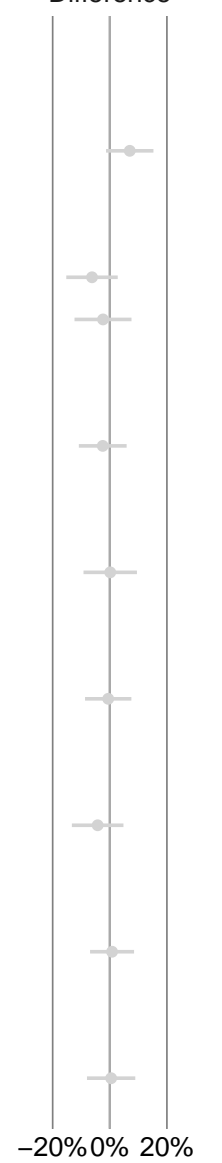

Average Marginal Component Effect 
Figure A6: Preferences among Democrats (public) for Republican vs. Democratic candidates

Democrats evaluate
Gender:
Male (Baseline)
Female
Race:
White (Baseline)
Black
Hispanic
Discrimination:
Not a big problem (Baseline)
Prevent discrimination
Taxes:
Less progressive (Baseline)
More progressive
Voting:
Opposes voter ID laws (Baseline)
Supports voter ID laws
Courts:
Obey courts (Baseline)
Disregard politicized decisions
Investigations:
Independent (Baseline)
Partisan involvement

Republican vs. Democratic candidates (public) Democratic candidates

Gender:

Male (Baseline)

Female

Race:

White (Baseline)

Black

Hispanic

iscrimination:

Not a big problem (Baseline)

Prevent discrimination

Less progressive (Baseline)

More progressive

oting ourts:

Obey courts (Baseline)

Disregard politicized decisions

nvestigations:

Independent (Baseline)

Partisan involvement

Compromise:

Supports compromise (Baseline)

$-20 \% 0 \% 20 \%$

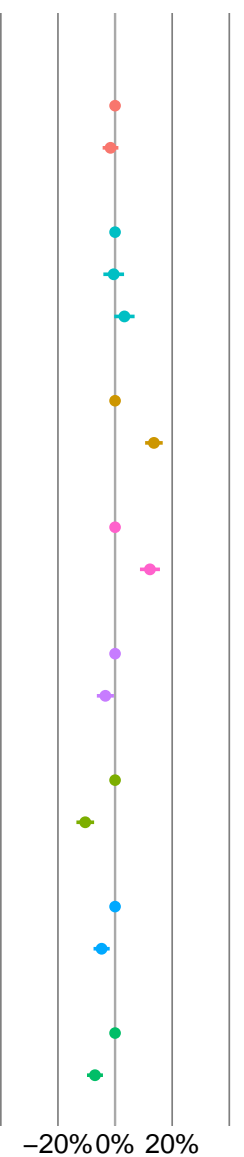

Difference

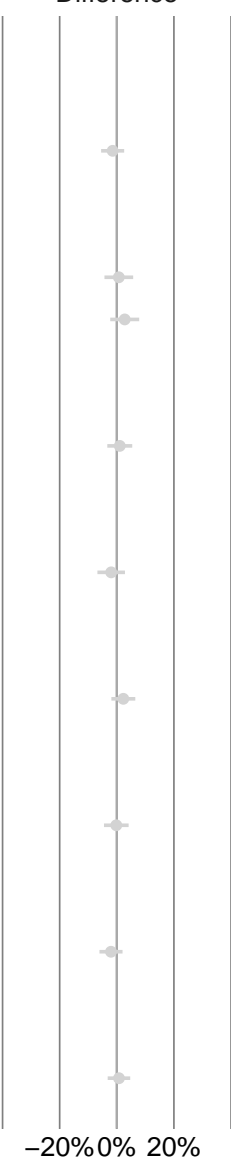

Average Marginal Component Effect 
Figure A7: Preferences among Democrats (donors) for Republican vs. Democratic candidates

\section{Democrats evaluate Republican vs. Democratic candidates (donors)}

Gender:

Male (Baseline)

Female

Race:

White (Baseline)

Black

Hispanic

Discrimination:

Not a big problem (Baseline)

Prevent discrimination

Taxes:

Less progressive (Baseline)

More progressive

Voting:

Opposes voter ID laws (Baseline)

Supports voter ID laws

Courts:

Obey courts (Baseline)

Disregard politicized decisions

Investigations:

Independent (Baseline)

Partisan involvement

Compromise:

Supports compromise (Baseline)

Stand up to other party

Republican candidates

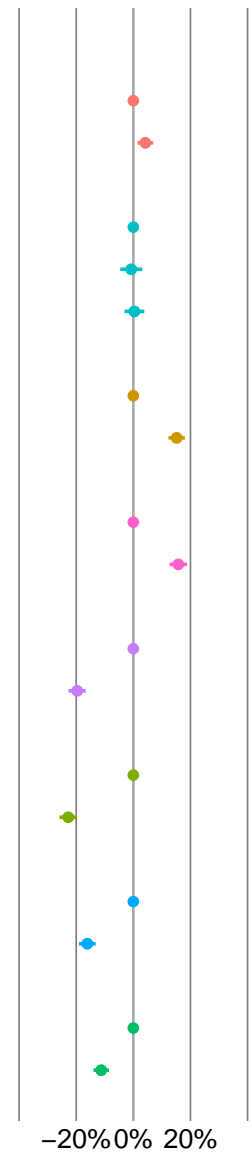

Democratic candidates

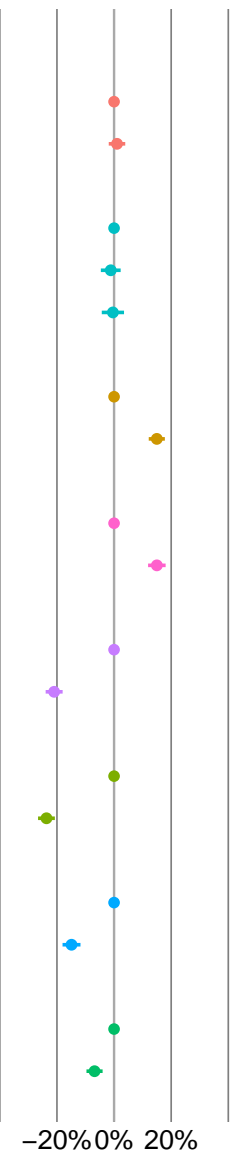

Difference

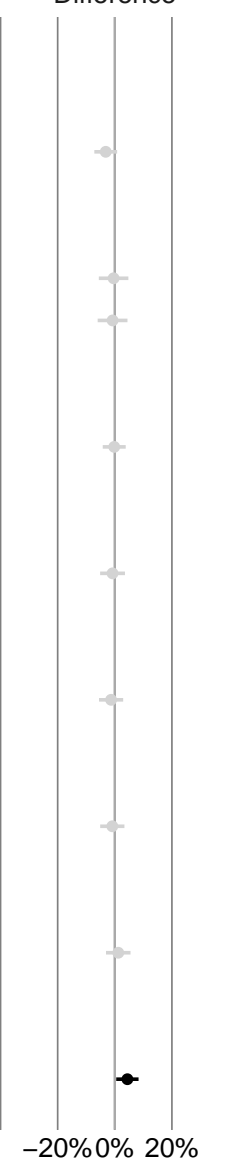

Average Marginal Component Effect 


\section{Predicted support probabilities for norm-violating candidates among donors}

Here we calculate predicted support probabilities for co-partisan candidates who violate shared democratic norms among donors (see the main text for analogous calculations among the public).

Among Republicans in the donor sample, a white, male, Republican candidate who holds traditionally conservative positions on discrimination, taxes, and voting rights ${ }^{3}$, and who does not transgress any democratic norms, has an $97.0 \%$ chance of being selected, averaged over all possible alternatives. If he transgresses one norm, that likelihood drops to between $77.1 \%$ and $93.4 \%$. If he transgresses two norms, the likelihood that he is chosen drops to between $70.5 \%$ and $86.7 \%$. Finally, if he transgresses all three democratic norms, the likelihood that he is chosen drops to $66.9 \%$.

Among Democrats in the donor sample, a white, male, Democratic candidate who holds traditionally liberal positions on discrimination, taxes, and voting rights, and who does not transgress any democratic norms, has n $100 \%$ chance $^{4}$ of being selected, averaged over all possible alternatives. If he transgresses one norm, that likelihood drops to between $80.0 \%$ and $94.3 \%$. If he transgresses two norms, the likelihood that he is chosen drops to between $64.6 \%$ and $78.8 \%$. Finally, if he transgresses all three democratic norms, the likelihood that he is chosen drops to $55.6 \%$.

\footnotetext{
${ }^{3}$ We hold party positions on ballot access fixed in line with the stance favored by each party because access to the ballot is the one democratic principle on which we found partisan polarization. To illustrate the scope of the effects of punishment for transgressions of principles on which we found pro-democracy consensus across party lines, our simulations examine changes in position on the other democratic norms.

${ }^{4}$ The predicted value (103\%) exceeds the possible range slightly.
} 


\section{References}

Bartels, Larry M. 2018. "Partisanship in the Trump Era.” Working paper, available at: https://www.vanderbilt.edu/csdi/includes/Workingpaper2_2108.pdf.

Bolsen, Toby, James N. Druckman, and Fay Lomax Cook. 2014. "The Influence of Partisan Motivated Reasoning on Public Opinion.” Political Behavior 36(2): 235-262.

Broockman, David, and Neil Malhotra. 2018. "What Do Donors Want? Heterogeneity by Party and Policy Domain." Working paper, avilable at SSRN: https://papers.ssrn.com/sol3/papers.cfm?abstract_id=3288862.

Broockman, David E. 2013. "Black Politicians Are More Intrinsically Motivated to Advance Blacks' Interests: A Field Experiment Manipulating Political Incentives.” American Journal of Political Science 57(3): 521-536.

Bullock, John G. 2011. "Elite Influence on Public Opinion in an Informed Electorate.” American Political Science Review 105(3): 496-515.

Butler, Daniel M., and Jonathan Homola. 2017. “An Empirical Justification for the Use of Racially Distinctive Names to Signal Race in Experiments.” Political Analysis 25(01): 122-130.

Campbell, Angus, Philip Converse, Warren Miller, and Donald Stokes. 1960. The American Voter. Chicago, IL: University of Chicago Press.

Carnes, Nicholas, and Noam Lupu. 2016. "Do Voters Dislike Working-Class Candidates? Voter Biases and the Descriptive Underrepresentation of the Working Class." American Political Science Review 110(4): 832-844.

DeSante, Christopher D. 2013. "Working Twice as Hard to Get Half as Far: Race, Work Ethic, and America's Deserving Poor.” American Journal of Political Science 57(2): 342-356. 
Doherty, David, Conor M Dowling, and Michael G Miller. 2018. "Do Party Chairs Think Women and Minority Candidates Can Win? Evidence from a Conjoint Experiment." Forthcoming at The Journal of Politics. Available at: http://thedata.harvard.edu/dvn/dv/jop.

Drutman, Lee, Larry Diamond, and Joe Goldman. 2018a. "Follow the Leader: Explaining American Support for Democracy and Authoritarianism.” Report prepared for the Democracy Fund Voter Study Group, available at: https://www.voterstudygroup.org/publications/2017-voter-survey/follow-the-leader.

Drutman, Lee, Larry Diamond, and Joe Goldman. 2018b. "Testing the Limits: Examining Public Support for Checks on Presidential Power." Report prepared for the Democracy Fund Voter Study Group, available at: https://www.voterstudygroup.org/publications/2017-voter-survey/testing-the-limits.

Foa, Roberto Stefan, and Yascha Mounk. 2016. “The Danger of Deconsolidation: The Democratic Disconnect." Journal of Democracy 27(3): 5-17.

Graham, Matthew, and Milan W. Svolik. 2019. "Democracy in America? Partisanship, Polarization, and the Robustness of Support for Democracy in the United States.” Working paper, available at SSRN: https://papers.ssrn.com/sol3/papers.cfm?abstract_id=3354559.

Hainmueller, Jens, Daniel J Hopkins, and Teppei Yamamoto. 2014. "Causal Inference in Conjoint Analysis: Understanding Multidimensional Choices via Stated Preference Experiments." Political Analysis 22(1): 1-30.

Holland, Steve, Jeff Mason, and James Oliphant. 2018. "Exclusive: Trump Worries That Mueller Interview Could Be A Perjury Trap.” August 20. https://www.reuters.com/article/us-usa-trump-mueller-exclusive/exclusive-trump-worries-thatmueller-interview-could-be-a-perjury-trap-idUSKCN1L526P. Reuters. (Last Accessed: June 6, 2019). 
Horiuchi, Yusaku, Daniel M. Smith, and Teppei Yamamoto. 2018. "Identifying Voter Preferences for Politicians' Personal Attributes: A Conjoint Experiment in Japan.” Forthcoming, Political Science Research and Methods.

Kirkland, Patricia A., and Alexander Coppock. 2018. "Candidate Choice Without Party Labels: New Insights from Conjoint Survey Experiments.” Political Behavior 40(3): 571-591.

Lavine, Howard G., Christopher D. Johnston, and Marco R. Steenberger. 2012. The Ambivalent Partisan: How Critical Loyalty Promotes Democracy. Oxford, UK: Oxford University Press.

McCarthy, Justin. 2016. "Four in Five Americans Support Voter ID Laws, Early Voting.” August 22. https://news.gallup.com/poll/194741/four-five-americans-support-voter-laws-earlyvoting.aspx?utm_source=tagrss\&utm_medium=rss\&utm_campaign=syndication. Gallup. (Last Accessed: June 6, 2019).

Ono, Yoshikuni, and Barry C. Burden. 2018. "The Contingent Effects of Candidate Sex on Voter Choice." Forthcoming, Political Behavior. Available at: https://link.springer.com/article/10.1007/s11109-018-9464-6.

Shepard, Steven. 2017. "Poll: Voters Divided on Comey Firing." May 11. https://www.politico.com/story/2017/05/11/poll-james-comey-firing-approval-238279. Politico. (Last Accessed: May 21, 2019).

Svolik, Milan W. 2018. "When Polarization Trumps Civic Virtue: Partisan Conflict and the Subversion of Democracy by Incumbents.” Working paper, available at: https://pdfs.semanticscholar.org/4d2c/50628b3333c52e6f0c7488cae125a996b3f3.pdf.

Twenge, Jean M., Nathan T. Carter, and W. Keith Campbell. 2015. "Time Period, Generational, and Age Differences in Tolerance for Controversial Beliefs and Lifestyles in the United States, 19722012." Social Forces 94(1): 379-399. 
Voeten, Erik. 2016. “Are People Really Turning Away from Democracy?” Journal of Democracy Web Exchange. Available at: https://www.journalofdemocracy.org/wpcontent/uploads/2018/12/Journal-of-Democracy-Web-Exchange-Voeten_0.pdf.

White, Ariel R., Noah L. Nathan, and Julie K. Faller. 2015. "What Do I Need to Vote? Bureaucratic Discretion and Discrimination by Local Election Officials.” American Political Science Review 109(01): 129-142. 